FOLIA HISTORICA CRACOVIENSIA, 21: 2015, s. 45-77

DOI: http://dx.doi.org/10.15633/fhc.1730

Jerzy Rajman

Uniwersytet Pedagogiczny w Krakowie

\title{
Kościoły bożogrobców w Małopolsce. Z badań nad patrociniami i relikwiami (XII-XVI w.)
}

Duchowość średniowiecznych zakonów wyrażała się w promowaniu zarówno uniwersalnych kultów świętych, jak i kultów typowych dla danego zakonu. Problematyka patrociniów w kościołach klasztornych, ważnych świadectw kultu i obecności świętych w przestrzeni, należy do bardzo ważnych zagadnień badawczych, ale słabo w polskiej literaturze zaawansowanych. Właściwie tylko Waldemar Rozynkowski zwrócił uwagę na to ważne zagadnienie. Spod jego pióra wyszły publikacje o patrociniach kościoła - cysterskiego w Pelplinie i dominikańskiego w Gdańsku . Zajął się także wezwaniami kościołów konwentualnych powstałych z fundacji monarszej ${ }^{2}$. Opublikował artykuł poświęcony patrociniom w zakonie kanoników regularnych lateraneńskich ${ }^{3}$ oraz klasztorów cysterek ${ }^{4}$. Są to najważniejsze w polskiej literaturze prace, w których za przedmiot badań

${ }^{1}$ W. Rozynkowski, Nie byli sami. Święci opactwa cysterskiego w Pelplinie, [w:] Pelplin: 725 rocznica powstania opactwa cysterskiego. Kulturotwórcza rola cystersów na Kociewiu, red. D. A. Dekański, B. A. Grenz, A. Słyszewska, A. M. Wyrwa, Pelplin-Tczew 2002, s. 59-70; W. Rozynkowski, Święci patronowie kościoła dominikanów w Gdańsku - wokót średniowiecznych wezwań dominikańskich w Polsce, [w:] Dominikanie. Gdańsk - Polska - Europa, pod red. D. A. Dekańskiego, A. Gołembnika, M. Grubki, Gdańsk-Pelplin 2003, s. 231-241.

${ }^{2}$ W. Rozynkowski, Patrocinia kościołów klasztornych fundacji władców polskich (XI-XV wiek). Wokól patronatu władcy?, [w:] Klasztor $w$ państwie średniowiecznym $i$ nowożytnym, pod red. M. Derwicha, A. Pobóg-Lenartowicz, Wrocław-Opole-Warszawa 2005, s. 31-44.

${ }^{3}$ W. Rozynkowski, Wezwania kościołów kanoników regularnych laterańskich w Polsce, ufundowanych do końca XV wieku. Zarys problematyki, [w:] Święty Stanisław Kazimierczyk CRL (14331489). Postać, środowisko, kultura, dziedzictwo, pod red. K. Łataka, Kraków 2010, s. 247-258; zob. także. A. Pobóg-Lenartowicz, Kult świętych $w$ ślaskich klasztorach kanoników regularnych $w$ średniowieczu, [w:] Ecclesia et civitas. Kościót i życie religijne w mieście średniowiecznym, red. H. Manikowska, H. Zaremska, Warszawa 2002, s. 439-452.

${ }^{4}$ W. Rozynkowski, Patrocinia kościołów cysterek w średniowiecznej Polsce - wokót duchowości zakonu, [w:] Cysterki w dziejach ziem polskich, dawnej Rzeczypospolitej i Europy Środkowej, red. A. M. Wyrwa, A. Kiełbasa, J. Swastek, Poznań 2004, s. 121-129. 
wzięto wezwania jednego zakonu. Postawiono także pytanie o patrocinia kościołów norbertańskich ${ }^{5}$. Problem wezwania kościoła pojawia się również, rzecz jasna, w monograficznych ujęciach poszczególnych klasztorów, a także w nielicznych opracowaniach poświęconych wezwaniom występującym na terenie danego miasta ${ }^{6}$. Do generalnych wniosków jest jeszcze daleko, przypomnieć jednak można fakt powszechnie znany, że wezwanie N. Marii Panny występuje w tytułach wszystkich kościołów cysterskich, przy każdym z nich umieszczane jest także wezwanie do jakiegoś świętego, co odróżnia dedykacje kościołów cysterskich. Zauważono również, że wezwanie Krzyża Świętego stanowi u polskich dominikanów aż 17 proc. wezwań głównych ${ }^{7}$. Wezwania maryjne i do Krzyża Świętego są charakterystyczne także dla średniowiecznych kościołów nieklasztornych. W epoce nowożytnej zwraca uwage popularność klasztornego wezwania św. Józefa ${ }^{8}$.

Patrocinia w kościołach bożogrobców nie były nigdy przedmiotem osobnego opracowania, aczkolwiek wiele informacji można spotkać w bogatej literaturze poświęconej zakonowi. Badacze koncentrowali się głównie na ukazaniu rozprzestrzeniania się wezwania Grobu Bożego'. Niektóre patrocinia miechowskich bożogrobców omówiła Maria Starnawska ${ }^{10}$. O kultach świętych w kościele miechowskim, odnosząc się również do kwestii wezwań, pisze także Ryszard

${ }^{5}$ J. Rajman, Przyczynki do zagadnienia duchowości Zakonu św. Norberta w Polsce, „Nasza Przeszłość” 97 (2002), s. 5-23; o patrociniach w tym zakonie, wykazującym wiele wspólnych cech duchowości z bożogrobcami, zob. N. Backmund, Monasticon Praemonstratense, id est historia circariarum atque canoniarum candidi et canonici ordinis Praemonstratensis, vol. 3, Straubing 1953, s. 501-509.

${ }^{6}$ J. Rajman, Średniowieczne patrocinia krakowskie, Kraków 2002.

7 W. Rozynkowski, Patrocinia kościołów klasztornych..., dz. cyt., s. 35.

${ }^{8}$ W. Rozynkowski, Św. Józef, patron kościołów zakonnych w Polsce ok. 1772 roku, „Kaliskie Studia Teologiczne" 3 (2004), s. 131-137.

${ }^{9}$ O wezwaniu Grobu Bożego pisali: F.-H. Beyer, Geheiligte Räume. Theologie, Geschichte und Symbolik des Kirchengebäudes. Wissenschaftliche Buchgesellschaft, Darmstadt 2008, s. 35 (w nawiązaniu do rozprzestrzeniania się kościołów pielgrzymkowych); J. Krüger, Die Grabeskirche zu Jerusalem. Geschichte - Gestalt - Bedeutung, Regensburg 2000, passim; P. Piva, Die "Kopien" der Grabeskirche im romanischen Abendland. Überlegungen zu einer problematischen Beziehung, [w:] Die Zeit der Kreuzzüge. Geschichte und Kunst, hrsg. von R. Cassanelli, Stuttgart 200o, s. 96-117; P. Warmbrunn, Das ehemalige Kloster vom Heiligen Grab in Speyer, [w:] Festschrift für Jürgen Keddigkeit zum 65. Geburtstag, Hrsg. B. Schuttpelz, P. Roland, Kaiserslautern 2012, s. 11-30; zob. także $\mathrm{w}$ tym artykule literaturę podaną $\mathrm{w}$ przypisach $14 \mathrm{i} 33$.

${ }^{10}$ M. Starnawska, Krucjata i Ziemia Święta $w$ duchowości zakonów krzyżowych $w$ Polsce średniowiecznej, „Saeculum Christianum” 3 (1996) nr 1, s. 167-179. 
Skrzyniarz ${ }^{11}$. W przypadku polskiej gałęzi zakonu należy podkreślić, iż zachowało się wiele dokumentów. Również sporo nieznanych dotąd informacji zawiera dzieło Samuela Nakielskiego ${ }^{12}$.

Problematyka wezwań stanowi, jak wiadomo, ważny element badań nad kultami świętych. Powinna być rozpatrywana w ścisłej łączności z poszukiwaniami wzmianek o średniowiecznych relikwiach ${ }^{13}$. Wezwania są poświadczone w źródłach pisanych, a ponadto w zdecydowanej większości przetrwały do dziś, natomiast po średniowiecznych relikwiach ślad, w większości przypadków, zaginął. Zjawisko to nie ominęło, niestety, również Miechowa.

Duchowość zakonu bożogrobców jawi się nam jako unikatowe zjawisko z uwagi na ścisłą, realną więź tego zakonu z Jerozolimą ${ }^{14}$. Miechów zajmuje $\mathrm{z}$ tego powodu szczególne miejsce w życiu religijnym dawnej Polski, co w literaturze

${ }^{11}$ R. Skrzyniarz, Kanonicy Grobu Bożego i ich religijny, społeczny, edukacyjny i kulturowy wkład w rozwój mieszkańców ziem polskich w średniowieczu, Lublin 2015, s. 355-359. Z monografią tą mogłem się zapoznać, z uwagi na rok wydania, dopiero na etapie korekty niniejszego artykułu. Problematykę kultów świętych u bożogrobców poruszali także H. Piwoński, Kult świętych w kalendarzach liturgicznych bożogrobców, „Muzyka Religijna w Polsce” 3 (1979), s. 167; F. Wolnik, Kalendarz nyskich bożogrobców według XIV-wiecznego Liber Ordinarius, „Studia Teologiczno-Historyczne Śląska Opolskiego" 15 (1995), s. 311-333; F. Wolnik, Święci w zabytkach liturgicznych nyskich bożogrobców, [w:] Człowiek i Kościół w dziejach: księga pamiątkowa dedykowana księdzu profesorowi Kazimierzowi Doli z okazji 65. rocznicy urodzin, red. J. Kopiec, Opole 1999, s. 147-165; ostatnio także A. Wędzki, Miechów w średniowieczu. Studia z dziejów miasta i klasztoru, zagadka Jaksy, Warszawa 2014, s. 132.

${ }^{12}$ S. Nakielski, Miechovia sive promptuarium antiquitatum Monasterii Miechoviensis, Cracoviae 1634 .

${ }^{13}$ J. Rajman, Święta, relikwie i patrocinia $w$ problematyce kultu świętych $w$ Krakowie od końca $\mathrm{x}$ do połowy XIII wieku, [w:] Kraków w chrześcijańskiej Europie, red. E. Firlet, Kraków 2006, s. 121-161; zob. klasyczną rozprawę Arnolda Angenendta, Heilige und Reliquien. Die Geschichte ihres Kultes vom frühen Christentum bis zur Gegenwart, München 1994, a w polskiej literaturze przede wszystkim prace Marii Starnawskiej; M. Starnawska, Rozmieszczenie i struktura zbiorów relikwii w polskich miastach średniowiecznych. Problematyka badawcza, [w:] Ecclesia et civitas. Kościót $i$ życie religijne $w$ mieście średniowiecznym, red. H. Manikowska i H. Zaremska, Warszawa 2002, s. 453-462; M. Starnawska, Świętych życie po życiu. Relikwie w kulturze religijnej na ziemiach polskich $w$ średniowieczu, Warszawa 2008.

${ }^{14}$ K. Elm, Kanoniker und Ritter vom Heiligen Grab. Ein Beitrag zur Entstehung und Frühgeschichte der palästinensischen Ritterorden, [w:] Die geistlichen Ritterorden Europas, Hrsg. J. Fleckenstein i M. Hellman, Sigmaringen 1980, s. 141-171 (Vorträge und Forschungen, 26); C. Dondi, The Liturgy of the Canons Regular of the Holy Sepulchre, Turnhout 2004; R. Skrzyniarz, Duchowość Zakonu Bożogrobców, [w:] Ludzie - Kościót - wierzenia. Studia z dziejów kultury i społeczeństwa Europy Środkowej (średniowiecze - wczesna epoka nowożytna). Księga pamiątkowa poświęcona Prof. Stanisławowi Bylinie, red. W. Iwańczak, S. K. Kuczyński, Warszawa 2001, s. 49-59. Znaczenie Jerozolimy w życiu duchowym ziem polskich ukazała H. Manikowska, Translatio Jerozolimy 
naukowej wielokrotnie jest podkreślane. W niniejszym artykule przedstawimy rezultaty kwerend zmierzających do zestawienia wszystkich wezwań, zarówno głównych, jak i wewnętrznych, czyli ołtarzowych, w kościołach administrowanych przez ten zakon. Omówimy również skąpe, lecz ważne, wzmianki o relikwiach. Ograniczamy się do terenu średniowiecznej Małopolski, gdyż odrębnych badań wymagają patrocinia kościołów bożogrobców w Wielkopolsce, ziemi dobrzyńskiej, w Sieradzu, na Śląsku, diecezji przemyskiej i na Spiszu. Bożogrobcy administrowali w średniowiecznej Małopolsce w sumie aż 12 kościołami, co daje solidną bazę do analizy patrociniów.

Jak powszechnie wiadomo, $\mathrm{w} 1163$ roku Jaksa sprowadził z Jerozolimy kanonika Bazyliki Grobu Pańskiego ${ }^{15}$. Ufundował kościół i klasztor, który niebawem wyrósł do rangi najważniejszego domu bożogrobców w naszym rejonie Europy. Należy, moim zdaniem, podtrzymać wysuwaną w literaturze tezę, że efektem pielgrzymki Jaksy było sprowadzenie relikwii wywodzących się z Ziemi Świętej i umieszczenie ich w najstarszym kościele miechowskim. Jedyna źródłowa relacja o tym pochodzi z dzieła S. Nakielskiego, który utrzymywał, że Jaksa przywiózł ziemię z miejsc związanych z Chrystusem. Podał nawet taki szczegół, że ziemia ta była w czterech workach ${ }^{16}$. Fragment ten ożywia toczoną od lat dyskusję i stanowi podstawę do wysuwania interesujących hipotez, np. Zbigniew Piłat wiąże z pielgrzymką Jaksy kasetkę, która do dziś zachowała się na Wawelu. W niej miała się znajdować owa ziemia przywieziona z pielgrzymki ${ }^{17}$. Fakt opisany przez

do Wrocławia, [w:] Kościót kultura społeczeństwo. Studia z dziejów średniowiecza i czasów nowożytnych, Warszawa 2000, s. 63-76.

${ }^{15}$ Kwestię pielgrzymki, bądź pielgrzymek, Jaksy rozważają: M. Starnawska, Między Jerozolimą a Łukowem. Zakony krzyżowe na ziemiach polskich w średniowieczu, Warszawa 1999, s. 64-65 oraz M. Gładysz, Zapomniani krzyżowcy. Polska wobec ruchu krucjatowego w XII-XIII wieku, Warszawa 2002, s. 106-107; J. Rajman, Pilger und Stifter. Zu den Sakralstiftungen und zur Herkunft des Fürsten Jaxa, [w:] Monarchische und adlige Sakralstiftungen im mittelalterlichen Polen, Hrsg. E. Mühle, Berlin 2013, s. 317-346 (tam starsza literatura); R. Skrzyniarz, Kanonicy Grobu Bożego..., dz. cyt., s. 58 i nn. Kwestia ta pojawia się także we wszystkich pracach na temat średniowiecznego Miechowa.

${ }^{16}$ S. Nakielski, Miechovia..., dz. cyt., s. 81.

${ }_{17}$ Z. Piłat, Fundator i fundacja klasztoru bożogrobców w Miechowie, [w:] Bożogrobcy w Miechowie, red. M. Affek, Miechów-Warszawa 1999, s. 37-39. Dopuszcza także, że skrzynka ta jest tożsama z relikwiarzem na ziemię z grobu św. Stanisława wzmiankowanym w 1563 roku oraz, że faktycznie relikwiarz ten nadal kryje ziemię przywiezioną z Palestyny przez Jaksę. Hipotezę tę podtrzymał R. Skrzyniarz. Autor uważa, że relikwiarz ten został bożogrobcom zrabowany przez ludzi księcia Władysława Łokietka, którzy wypędzili kanoników z Miechowa w okresie tzw. buntu wójta Alberta. Z starszej literatury zob. M. Tobiasz, Bożogrobcy w Miechowie ( $w$ 8oo-lecie sprowadzenia zakonu do Polski), „Nasza Przeszłość” 17 (1963), s. 13. 
S. Nakielskiego znakomicie mieści się w realiach epoki, bowiem jednym z efektów pielgrzymek było pojawienie się grudek ziemi lub kamieni oraz ampułek z wodą zbieranych w miejscach pobytu Pana Jezusa ${ }^{18}$. Maria Starnawska zwróciła uwagę, że kamienie pochodzące z Grobu Świętego były w średniowiecznej Europie bardzo rozpowszechnione ${ }^{19}$. Faktem jest jednak, że nie wiemy, co było podstawą źródłową informacji S. Nakielskiego. Możliwe, że jest to dowód bardzo późnej tradycji ${ }^{20}$, czy też nawet posiadania jakichś źródeł, które do naszych czasów nie dotrwały $^{21}$. Jakkolwiek było, nie sposób tego przekazu lekceważyć, przede wszystkim $z$ uwagi na fakt, że kościoły i ołtarze były fundowane w oparciu o relikwie ${ }^{22}$. Ponieważ istnieje ścisły związek między relikwią a konsekracją kościoła, to istnieje, wobec tego, również związek patrocinium z relikwią. Wezwanie kościoła miechowskiego, jak też wezwanie ołtarza głównego w tym kościele ${ }^{23}$, stanowi

${ }^{18}$ E. Jastrzębowska, Najstarsze zachowane dewocjonalia pielgrzymie z Jerozolimy, [w:] Jerozolima $w$ kulturze europejskiej, red. P. Paszkiewicz, T. Zadrożny, Warszawa 1997, s. 59; K. Szczepkowska-Naliwajek, Relikwiarze średniowiecznej Europy od IV do początku xvi wieku. Geneza, treści, styl i technika wykonania, Warszawa 1996, s. 68-69; E. D. Hehl, Kreuzzug - Pilgerfahrt - Imitatio Christi, [w:] Pilger und Wallfahrtstätten in Mittelalter und Neuzeit, Hrsg. M. Matheus, Stuttgart 1999, s. 35-51; J. Žemlička, Wallfahrten aus Böhmen nach dem Heiligen Land und ihre kulturelle Bedeutung (bis Mitte des 12. Jahrhunderts), [w:] Wallfahrten in der europäischen Kultur. Pilgrimage in European Culture, Hrsg. D. Doležal und H. Kühne, Frankfurt am Main 2006, s. 37-52. Ostatnio F. Reichert, Nabel der Welt, Zentrum Europas und doch nur Peripherie? Jerusalem in Weltbild und Wahrnehmung des späten Mittelalters, [w:] „Zeitschrift für Historische Forschung” 38 (2011) nr 4, s. 559-584 ukazuje, że w późnym średniowieczu pielgrzymi przywozili z Ziemi Świętej piasek, kamienie lub wodę.

${ }^{19}$ M. Starnawska, Świętych życie po życiu..., dz. cyt., s. 37. Autorka powołuje się na pracę: O. Halaga, Počatky Košic a zrod metropoly, Košice 1992, który dopuszczał możliwość, że joannici przywieźli do Koszyc ampułkę z krwią Chrystusa, ale wskazuje, że kult tej relikwii został poświadczony dopiero w drugiej poł. XIV wieku.

${ }^{20}$ Akcentuje ten fakt ostatnio A. Wędzki, Miechów w średniowieczu..., dz. cyt., s. 49.

${ }^{21}$ Kwestia źródeł S. Nakielskiego to temat na osobne opracowanie, por. W. Bukowski, Miechów - klasztor, [w:] Słownik historyczno-geograficzny województwa krakowskiego w średniowieczu, oprac. W. Bukowski, J. Laberschek, A. Marzec, M. Zdanek, przy współpr. S. Kołodziejskiego, cz. IV, z. 2, Kraków 2009, s. 395 i 420 przypis 67, gdzie przekonywująca teza o zaginionych księgach zmarłych; zob. także A. Chojnacki, Dwie wersje "Rocznika miechowskiego” oraz jego nieznana kontynuacja ( $w$ świetle analizy „Miechovii” Samuela Nakielskiego), „Hereditas Monasteriorum” 1 (2012), s. $57-71$.

${ }^{22}$ P. Sczaniecki, Sacramentum dedicationis. Obrzęd poświęcenia kościoła i jego znaczenie $w$ dziedzinie religijnej, obyczajowej i kulturalnej na podstawie źródeł staropolskich $z$ XII wieku, Lublin 1979, s. 42-43; G. Ryś, Teologia relikwii w średniowieczu, [w:] Kult świętych w Polsce średniowiecznej, red. E. Piwowarczyk, R. M. Zawadzki, Kraków 2003, s. 27-36.

${ }^{23}$ Zob. w tym artykule niżej s. 62. 
pośredni, lecz ważny dowód istnienia relikwii jerozolimskich. Należy podkreślić, że w przypadku Miechowa mamy do czynienia nie tylko z szczęśliwym powrotem możnego Jaksy z pielgrzymki, ale również z faktem o znaczeniu unikatowym, a mianowicie przybyciem przynajmniej jednego zakonnika wprost $\mathrm{z}$ klasztoru opiekującego się Grobem Pańskim w Jerozolimie. Wielka popularność miechowskiej konfraterni Grobu Pańskiego w pierwszych półwieczu po fundacji jest także istotną przesłanką za tezą o sprowadzeniu do Miechowa relikwii związanej z Grobem Pańskim w Jerozolimie.

Należy zauważyć, że żadne ze źródeł średniowiecznych nie wymienia relikwii miechowskich, co dotyczy nie tylko relikwii Grobu Pańskiego, ale także jakichkolwiek innych. Nakielski dostarcza świadectw, że kościół bożogrobców przechowywał relikwie. Świadczy o tym cytowana przez niego in extenso bulla papieża Eugeniusza IV z 1438 roku, w której jest mowa o relikwiach należących do kościoła w Miechowie ${ }^{24}$. Autor ten pisał także, że prepozyt Michał z Radomska sprawił relikwiarze dla kościoła w Miechowie ${ }^{25}$. Inny, ważny przekaz historyka bożogrobców o relikwiach, umknął uwadze badaczy, zapewne z tego powodu, że został zamieszczony w relacji o wydarzeniach z 1584 roku Zapisał, że zanim prepozyt Andrzej Batory sprowadził liczne partykuły świętych, kościół miechowski miał sławne i liczne relikwie, którymi niejedna katedra mogła się poszczycićc ${ }^{26}$. Wymienia, jednak, tylko dwie, w tym najważniejszą, a mianowicie relikwię Krzyża Świętego sprowadzoną z Jerozolimy. Przypomnieć należy, że już Jerzy Pietrusiński uważał, że w Miechowie znajdowały się relikwie Krzyża Świętego, dla których wykonano w drugiej połowie XIV wieku relikwiarz ${ }^{27}$. W kontekście wiarygodnej relacji Nakielskiego teza ta zasługuje na uznanie ${ }^{28}$. Należy podkreślić, że posia-

${ }^{24}$ S. Nakielski, Miechovia..., dz. cyt., s. 462.

${ }^{25}$ S. Nakielski, Miechovia..., dz. cyt., s. 390; w zapiskach „Rocznika miechowskiego” (wyd. Z. Kozłowska-Budkowa, „Studia Źródłoznawcze” 5 [1960], s. 128-132), ukazujących bardzo szczegółowo fundatorską działalność prepozyta Michała, nie ma wzmianki o tych relikwiarzach. Nie wydaje mi się, aby Nakielski samowolnie rozszerzył tę relację, sądzę, że miał w ręku niezachowane świadectwo źródłowe.

${ }^{26}$ S. Nakielski, Miechovia..., dz. cyt., s. 738.

${ }^{27}$ J. Pietrusiński, Relikwiarz z Korzkwi, „Biuletyn Historii Sztuki” 43 (1981) nr 2, s. 128-132.

${ }^{28}$ M. Starnawska, Świętych życie po życiu..., dz. cyt., s. 105 zwraca uwagę, że w okresie X-XII wieku wezwanie Krzyża Świętego na ziemiach polskich należy do rzadkich; w tejże publikacji (s. 107) podjęte zostało krytyczne rozpatrzenie hipotezy o ofiarowaniu przez Jaksę relikwii Krzyża Świętego i podarowanie jej kolegiacie w Łęczycy. O kulcie Krzyża św. u miechowskich bożogrobców świadczy wezwanie Krzyża św., jakie nosił ufundowany w 1295 roku i oddany bożogrobcom szpital pod Raciborzem. Wezwanie to jest tam poświadczone już w 1302 roku, zob. N. Mika, Bożogrobcy raciborscy $w$ średniowieczu, [w:] Klasztor w mieście średniowiecznym i nowożytnym, red. 
danie tej relikwii przez klasztory powstałe w kręgu rodzinnym Jaksy jest znane w literaturze. Tytułem przykładu można podać, że relikwię Krzyża Świętego posiadali, prawdopodobnie od XII wieku, premonstratensi opactwa na Ołbinie pod Wrocławiem ${ }^{29}$. Relikwie Krzyża Świętego zostały poświadczone także w 1216 roku, jako partykuła wmurowana do ołtarza kościoła klasztornego w Strzelnie. Co ciekawe, wraz z nią znalazła się tam również bliżej niekreślona relikwia Grobu Pańskiego ${ }^{30}$. Jest to znakomity przykład fundowania ołtarza na relikwiach. Zaryzykowałbym przypuszczenie, że jeśli któryś z klasztorów powstałych w XII wieku miałby posiadać jako pierwszy relikwie Krzyża św. i Grobu Bożego, to byłby właśnie kościół w Miechowie - fundacja pielgrzyma Jaksy. Istnienie relikwii Krzyża św. w kościele miechowskim może być wytłumaczeniem częstych wizyt Władysława Jagiełły w mieście bożogrobców ${ }^{31}$.

Wybór świętego patrona, któremu powierzano własność kościoła i opiekę nad określoną przestrzenią sakralną ${ }^{32}$ był uzależniony od kilku czynników, których

M. Derwich, A. Pobóg-Lenartowicz, Wrocław-Opole 200o, s. 421nn. Najwcześniejszym przykładem wystąpienia patrocinium Krzyża św. w małopolskim kościele bożogrobców jest konsekracja kościoła w Żarnowcu w 1404 roku, zob. niżej s. 59; o kulcie Krzyża u bożogrobców nyskich pisze F. Wolnik, Święci w zabytkach liturgicznych..., dz. cyt., s. 157, u miechowitów zob. A. Wędzki, Miechów w średniowieczu..., dz. cyt., s. 49-50. Kult Krzyża nie jest specyfiką bożogrobców, przenika on bowiem wszystkie instytucje religijne chrześcijaństwa. O specyfice bożogrobców możemy mówić natomiast w kontekście połączenia kultu Krzyża z kultem Grobu; por. J. E. A. Kroesen, The Sepulchrum Domini through the Ages Its Form and Function, Leuven 2000, s. 12, który ukazuje, jakie znaczenie dla kształtowania duchowości człowieka w średniowieczu (ale i dzisiaj) ma fakt przejścia w kościele od krucyfiksu do Grobu. Istotne jest też to, że Grób jest pusty - tylko taki bowiem symbolizuje Zmartwychwstanie.

${ }^{29}$ M. Starnawska, Świętych życie po życiu..., dz. cyt., s. 110.

${ }^{30}$ Z. Kozłowska-Budkowa, Płockie zapiski o cudach $z$ r. 1148, „Kwartalnik Historyczny” 44 (1930), s. 342; M. Starnawska, Świętych życie po życiu..., dz. cyt., s. 117.

${ }^{31}$ J. Rajman, Jagiellonowie a klasztor bożogrobców w Miechowie, [w:] Jagiellonowie i ich świat. Dynastia królewska w drugiej połowie XV $i$ w XVI wieku, pod red. B. Czwojdrak, J. Sperki, P. Węcowskiego [seria: Studia Jagiellonica, red. M. Koczerska, M. Walczak, P. Węcowski, t. 2], Kraków 2016 (w druku). O dynastycznym kulcie Krzyża św. Zob. U. Borkowska, Pietas regia. Formy królewskiej pobożności w późnośredniowiecznej Polsce, [w:] Król w Polsce XIV i XV wieku, red. A. Marzec, J. Wilamowski, Kraków 2006, s. 43; U. Borkowska, Życie religijne polskich Jagiellonów. Zarys problematyki, [w:] Chrzest Litwy. Geneza, Przebieg, Konsekwencje, red. M. T. Zahajkiewicz, Lublin 1990, s. 153.

${ }^{32}$ W. Rozynkowski, Wezwania kościołów kanoników regularnych laterańskich..., dz. cyt., s. 245, definiuje patrocinium jako „określenie opieki świętych nad miejscami”. O fundacji i dedykacji kościoła jako akcie uświęcającym przestrzeń, pisze H. Manikowska, Geografia sakralna miasta, [w:] Animarum kultura. Studia nad kulturą religijną na ziemiach polskich w średniowieczu, t. 1: Struktury kościelno-polityczne, pod red. H. Manikowskiej i W. Brojera, Warszawa 2008, s. 101. 
ścisłej hierarchii nie zawsze można się dopatrzeć. Wymienimy popularność kultu, wolę biskupa, wolę wspólnoty zakonnej wynikającą ze specyfiki jej duchowości i wolę fundatora uwarunkowaną np. złożonym ślubowaniem albo poczuciem wdzięczności wobec danego patrona. Można te czynniki ułożyć także w innej kolejności. Dodać do tej listy należy również występujący czasami mit cudowności danego miejsca, co jest zagadnieniem stosunkowo mało zbadanym. W przypadku fundacji i dedykacji kościoła w Miechowie oddziałała większość z wymienionych tu czynników. Nowy zakon przyniósł do Polski kult Grobu Bożego i takie właśnie wezwanie otrzymał kościół w Miechowie. Patrocinium Grobu Pańskiego należy do typowych wezwań kościołów pielgrzymkowych, co wskazuje, że od samego początku jego twórcom przyświecała idea stworzenia repliki bazyliki jerozolimskiej, która przyciągałaby pielgrzymów. Często występuje ono wśród najstarszych kościołów zakonu, czego przykładem są świątynie w Acon, w Mons Peregrinus koło Tripolis, na terenie Italii np. w Brindisi i w Barletta oraz w Calatao w Hiszpanii ${ }^{33}$. Jego zasięg nie ogranicza się jednak tylko do kościołów zakonu bożogrobców. Usytuowanie w Miechowie bazyliki Grobu Bożego wyznaczało mu absolutnie wyjątkowe miejsce w życiu religijnym Polaków. Oczywistym jest, że kanonicy miechowscy propagowali przez owo patrocinium, a także przez specyficzną liturgię, kult Chrystusa zmartwychwstałego. Zagadnienie to posiada, jak wiadomo, bardzo bogatą literaturę.

Nawiązując do kwestii ściśle związanych z patrociniami, należy przypomnieć, że biskup krakowski Gedko „in honore sancti Sepulcri consecrauit” kościół

${ }^{33} \mathrm{O}$ doniosłym miejscu w duchowości chrześcijańskiej bazyliki Grobu Pańskiego w Jerozolimie i jej replik pisało wielu badaczy, przede wszystkim K. Elm, Umbilicus Mundi. Beiträge zur Geschichte Jerusalems, der Kreuzzüge, des Ordens der regulierten Chorherren vom Heiligen Grab und der Ritterorden ("Instrumenta Canonissarum Regularium Sancti Sepulcri”, 7), Brügge 1998, pass.; G. Roth, Das „Heilige Grab” in Görlitz, [w:] Der Jakobuskult in Ostmitteleuropa, Hrsg. K. Herbers i D. R. Bauer, Tübingen 2003, s. 259-284; ostatnio J. Krüger, Jerusalem - Rom Santiago. Drei Pilgerziele im Vergleich, [w:] Heiliges Grab - Helige Gräber. Aktualität und Nachleben von Pilgerorten, Hrsg. U. Röper, M. Treml, Berlin 2014, s. 24-32; o kaplicach Grobu, zob. W. Ehbrecht, Überall ist Jerusalem, [w:] Konsens und Konflikt: Skizzen und Überlegungen zur älteren Verfassungsgeschichte deutscher Städte, Hrsg. W. Ehbrecht, P. Johanek, Köln-WeimarWien 2001, s. 429-472, zwłaszcza s. 460 i nast., gdzie także ważne uwagi na temat patrocinium Grobu; C. Morris, The Sepulchre of Christ and the Medieval West: From the Beginning to 16oo, Oxford-New York 2005, pass. O tym patrocinium zob. także J. E. A. Kroesen, The Sepulchrum Domini through the Ages..., dz. cyt., s. 29-43, a dla późnego średniowiecza C. Schuchard, Zur Stiftungstätigkeit der Hohenzollern und ihrer Vertrauten in der Mark Brandenburg im 15. und frühen 16. Jahrhundert, [w:] Die Mark Brandenburg unter den frühen Hohenzollern. Beiträge $z u$ Geschichte, Kunst und Architektur im 15. Jahrhundert, Hrsg. P. Knüvener, D. Schumann, Berlin 2015 , s. 48 . 
w Miechowie ${ }^{34}$. Świadczy to, że biskup w pełni aprobował wybór wezwania, które ogłoszono wraz z towarzyszącym mu liturgicznym obrzędem poświęcenia $^{35}$. Wezwanie zostało kilkakrotnie poświadczone we wczesnych dokumentach miechowskich. W 1198 roku wspominano o "ecclesiae sancti Sepulchri” ${ }^{36}$. W dokumencie z 1230 roku czytamy, że pewien komes nadaje wieś „ecclesie Miechou nomine Sancti Sepulchri fundatae" ${ }^{37}$. Dokument wojewody krakowskiego Marka potwierdza nadanie innej wsi „ecclesie Miechoviensis Sancto Sepulchro pertinenti" ${ }^{38}$. Książę Henryk Brodaty w 1232 roku potwierdzał posiadanie wsi Chełm "ecclesiae Sancti Sepulchri in Miechow"39. W bullach papieża Urbana IV wspomina się o „ecclesiae Dominici Sepulchri”, bądź o „ecclesiae sancti Sepulchri de Miechovia" ${ }^{30}$. Nie może być najmniejszej wątpliwości, że od samego początku towarzyszyło to wezwanie świątyni miechowskiej. Jest to pierwszy jego przykład w Polsce. Patrocinium to figuruje także, jak wiadomo, w oficjalnej nazwie zakonu. Wymienię tylko kilka przykładów: w 1208 roku wzmiankowani są „fratres Dominici Sepulchri in Polonia”, w 1217 roku "domus sancti Sepulchri in Miechow”, w 1248 roku „domus Mechoviensis, ordinis Dominici Sepulchri”, w 1274 roku „fratres Dominici Sepulchri de Mechov"41. To tylko kilka przykładów wybranych z niezwykle bogatej w tej kwestii dokumentacji źródłowej. Nomenklatura ta była ważnym nośnikiem pojęcia Grobu Bożego w społecznej świadomości.

Nowość w problematyce wezwania miechowskiego stanowi wzmianka w bulli papieża Innocentego IV z 1247 roku, który zwraca się do miechowitów, jako „braci kościoła Najświętszej Maryi Panny zakonu świętego Grobu”"2. Jest to pierwszy ślad istnienia patrocinium maryjnego przy kościele miechowskim, ale nie jedyny. Można ostrożnie przypuszczać, że wezwanie maryjne pojawiło się przy konsekracji drugiego kościoła miechowskiego. Tu znów z pomocą przychodzi S. Nakielski, który pisze, że biskup krakowski Wisław dokonał konsekracji tego nowego kościoła $^{43}$. Ta faza architektonicznych przemian sanktuarium miechowskiego

${ }^{34}$ Kodeks dyplomatyczny Małopolski, t. 1-4, wyd. F. Piekosiński, Kraków 1876-1905 [dalej: KMp.], t. 2, nr 376.

${ }^{35}$ P. Sczaniecki, Sacramentum dedicationis..., dz. cyt., s. 9o. Autor podaje, jako synonimy pojęcia patrocinium, terminy tytuł, patronat i dedykacja.

${ }^{36}$ KMp. 2, nr 375 i 376.

${ }^{37}$ Kмp. 2, nr 401; S. Nakielski, Miechovia..., dz. cyt., s. 153.

${ }^{38}$ кмp. 2, nr 400; S. Nakielski, Miechovia..., dz. cyt., s. 153.

${ }^{39}$ кмp. 2, nr 405; S. Nakielski, Miechovia..., dz. cyt., s. 154.

${ }^{40}$ Kмp. 2, nr 623; S. Nakielski, Miechovia..., dz. cyt., s. 186-187, 337.

${ }^{41}$ KMp. 2, nr 378,384, 621, 625.

${ }^{42}$ KMp. 2, nr 428.

${ }^{43}$ S. Nakielski, Miechovia..., dz. cyt., s. 157. 
ma już swoją literaturę $e^{44}$. Przywilej odpustowy papieża Innocentego IV z 1251 roku ma niewątpliwie związek z świątynią konsekrowaną przez biskupa Wisława $^{45}$. Przy tej konsekracji pojawiło się wezwanie do N. Marii Panny. Nakielski starał się wyjaśnić genezę jeszcze jednego patrocinium w dedykacji kościoła miechowskiego. Twierdził, że gdy Miechów został zniszczony w 1287 roku przez Tatarów, pojawiła się konieczność powtórnej konsekracji. W jej wyniku otrzymał on nowe wezwanie Ducha św. Kronikarz klasztorny przypominał zarazem, że biskup Gedko konsekrował kościół pw. Grobu Pańskiego ${ }^{46}$, co stanowi wyraźny dowód zainteresowania Nakielskiego losami tytułu kościoła. Gdy w 1345 roku nastała potrzeba powtórnej konsekracji kościoła klasztornego (po profanacji dokonanej przez wojska czeskie), potwierdzono, że nosi on wezwanie Grobu Pańskiego i N. Marii Panny ${ }^{47}$. Wiadomość o konsekracji i dodaniu wezwania Ducha św. także zasługuje na wiarę, bowiem wezwanie Ducha św. jest źródłowo poświadczone. W dokumencie z 1544 roku, kiedy ogłaszano wybór Jana ze Lwówka na prepozyta miechowskiego, kościół konwentualny w Miechowie jest wzmiankowany z wezwaniem Ducha św. ${ }^{48}$. Bulla papieża Urbana viı z 1626 roku odnotowuje bractwo Grobu Pańskiego „w kościele parafialnym św. Ducha w Miechowie". Bulla ta wymienia również obowiązki mszalne konfratrów ${ }^{49}$, których tu opisywać nie będziemy, ważne jest natomiast, że dokumentuje ona nadal używanie omawianego patrocinium. Oprócz wezwania podstawowego, czyli poświadczonego w setkach wzmianek patronatu Grobu Pańskiego, w tytule kościoła miechowskiego występowały także co najmniej dwa inne wezwania: N. Marii Panny i Ducha Świętego. Jan Długosz, który wielokrotnie wzmiankuje kościół miechowski, tytułuje go zawsze tylko wezwaniem Grobu Pańskiego, pomijając patrocinium N. Marii Panny i Ducha Świętego ${ }^{50}$.

${ }^{44}$ Zbiera ją A. Wędzki, Miechów w średniowieczu..., dz. cyt., s. 128-129.

${ }^{45}$ Bullarium Poloniae I: 100o-1342, ed. I. Sułkowska-Kuraś, S. Kuraś, Romae 1982, nr 503; zwraca na to uwagę A. Wędzki, Miechów w średniowieczu..., dz. cyt., s. 128, który jednak pomija znaczenie bulli z 1247 roku dla tej problematyki.

${ }^{46}$ S. Nakielski, Miechovia..., dz. cyt., s. 219.

47 „Rocznik miechowski”, dz. cyt., s. 125; S. Nakielski, Miechovia..., dz. cyt., s. 262 także pisał pod 1346, że kościół w Miechowie został sprofanowany przez wojska Jana Luksemburczyka.

${ }^{48}$ S. Nakielski, Miechovia..., dz. cyt., s. 638.

${ }^{49}$ S. Nakielski, Miechovia..., dz. cyt., s. 120-121.

${ }^{50}$ Analizując zapiski o wezwaniu głównym kościoła miechowskiego nie napotkałem na wezwanie św. Jakuba Młodszego, o którym wspominają autorzy Katalogu zabytków sztuki. Województwo krakowskie, red. J. Szablowski, t. 1, z. 8, Warszawa 1953, s. 21, a za nimi R. Skrzyniarz, Kanonicy Grobu Bożego..., dz. cyt., s. 357. 
Klasztor bożogrobców, znany z istniejącej w drugiej połowie XII wieku konfraternii Grobu Pańskiego, został niezwykle bogato uposażony przez książąt, biskupów i możnowładców. Otrzymał w drugiej połowie xiI wieku także dwa kościoły poza Miechowem, co nakazuje spojrzeć na problem patrociniów tego zakonu szerzej - na wszystkie kościoły administrowane przez bożogrobców, również otrzymane $\mathrm{w}$ wyniku nadania wraz $\mathrm{z}$ wezwaniem. Kościoły nadane przez możnych, jako wspomożenie fundacji Jaksy, znajdowały się w Chełmie nad Rabą oraz w Skaryszewie koło Radomia.

Trzeba zasygnalizować tutaj kwestię konieczności ustalenia dokładnego czasu ich powstania. Dokument z 1198 roku jest, jak wiadomo, pierwszym świadectwem istnienia kościołów w Chełmie i Skaryszewie. Wchodzą w zakres rozważań dwie możliwości - pierwsza, że kościoły te powstały, zanim jeszcze Jaksa udał się na pielgrzymkę i ufundował klasztor oraz druga, że kościoły te zostały wybudowane dla zakonu bożogrobców. Kwestia ta ma duże znaczenie z uwagi na wezwanie, jakie nosił kościół w Skaryszewie. Wspomina się o nim w „Album patriarchale" z 1198 roku, że konsekrował go i uposażył dziesięcinami biskup krakowski Gedko. Zarówno komes Radosław, który kościół ofiarował, jak i Gedko, są wymienieni w tym źródle jako konfratrzy bożogrobców ${ }^{51}$. Podkreślić należy, że wezwanie św. Jakuba Apostoła w Skaryszewie zostało poświadczone już w 1234 roku$^{52}$ Wezwanie to, jakie nosił drewniany kościół w Skaryszewie, odnotowano także w protokole powizytacyjnym z końca Xvi wieku ${ }^{53}$. Nie może zatem być wątpliwości, że było to wezwanie główne tego kościoła, nadane przy konsekracji dokonanej przez biskupa Gedkę. Kościół skaryszewski pojawia się w literaturze naukowej jako wczesny przykład kultu św. Jakuba Apostoła tzw. Starszego ${ }^{54}$. W związku z tym postawiono ważne pytanie: który św. Jakub był

${ }^{51}$ Kмp. 2, nr 376; cytuje to S. Nakielski, Miechovia..., dz. cyt., s. 82 i 107; M. Niwiński, Ród panów na Wierzbicy, „Miesięcznik Heraldyczny” 10 (1931) nr 2, s. 29-30, datował konsekrację kościoła w Skaryszewie na ok. 1167 rok; znaczenie tej zapiski podkreślał także M. Tobiasz, Bożogrobcy w Miechowie..., dz. cyt., s. 15; o konfratrach pisał również Z. Piłat, Fundator i fundacja..., dz. cyt., s. 37.

${ }^{52}$ KMp. 2, nr 410; dokument ten in extenso zamieszcza S. Nakielski, Miechovia..., dz. cyt., s. 158.

${ }_{53}$ Archiwum Kurii Metropolitalnej w Krakowie [dalej: AKM], rps, Avcap. 65, s. 290. Jan Długosz (Liber beneficiorum dioecesis Cracoviensis, vol. 1-3, wyd. A. Przezdziecki, Cracoviae 1863-1864 [dalej: Dlb]) w tomie 2, s. 527 podał, że miasteczko jest własnością bożogrobców oraz, że ze Skaryszewa pochodził mistrz Jakub, ale wezwanie pominął milczeniem. Wszystkie informacje z drukowanej wersji Liber beneficiorum konfrontowałem z tzw. autografem przechowywanym w Archiwum Kapituły Krakowskiej.

${ }^{54}$ A. Witkowska, Das Patrozinium des hl. Apostels Jakobus in der mittelalterlichen Diözese Krakau, [w:] Der Jakobuskult in Ostmitteleuropa, Hrsg. K. Herbers i D. R. Bauer, Tübingen 2003, 
patronem tego kościoła. S. Nakielski odnotował bowiem, że biskup Gedko konsekrował w Skaryszewie kościół św. Jakuba „pierwszego i najważniejszego biskupa Jerozolimy"55, a zatem św. Jakuba Młodszego. Święty ten był jednym z głównych patronów zakonu bożogrobców ${ }^{56}$. Maria Starnawska wysunęła hipotezę, że pod wpływem bożogrobców św. Jakub Starszy uległ w Skaryszewie zmianie na św. Jakuba Młodszego ${ }^{57}$. A może wezwanie św. Jakuba Mniejszego dodano do pierwotnego tytułu? Kwestia ta wymaga dalszych badań, uwzględniających wszystkie przekazy źródłowe ${ }^{58}$.

Świętego Jana Chrzciciela, jako patrona kościoła w Chełmie, odnotowuje Jan Długosz i protokoły powizytacyjne ${ }^{59}$. Ofiarodawcą był komes Mikora, o którym wspomina się w 1198 roku, że przywdział habit konfratra. Brak jest jednak wzmianki, w odróżnieniu od Skaryszewa, o konsekracji kościoła chełmskiego ${ }^{60}$. Nakielski podaje, że w 1411 roku prepozyt Michał z Radomska wystawił nowy budynek kościoła, ale pod tym samym wezwaniem, co poprzednio, czyli św. Jana Chrzciciela $^{61}$. W dokumencie biskupa krakowskiego Jana z 1486 roku wzmiankowany jest „kościół św. Jana Chrzciciela” w Chełmie ${ }^{62}$, co można traktować jako dodatkowe potwierdzenie istniejącego tu od XII wieku wezwania. Św. Jan Chrzciciel, jako patron kościoła w Chełmie, występuje samotnie, nie są znane

s. 113-136, zwłaszcza s. 121 i 124; T. Dunin-Wąsowicz, Wezwanie św. Jakuba na tle innych patrociniów Sandomierszczyzny, [w:] Sedes Regni principales, red. B. Treliñska, Sandomierz 1999, s. 51-56.

${ }^{55}$ S. Nakielski, Miechovia..., dz. cyt., s. 107. Oba dokumenty z 1198 roku nie wymieniają wezwania kościoła w Skaryszewie, zob. Kмp. 2, nr 375-376.

${ }^{56}$ K. Elm, Kanoniker und Ritter..., dz. cyt., s. 150; H. Piwoński, Kult świętych..., dz. cyt., s. 167; F. Wolnik, Święci w zabytkach liturgicznych..., dz. cyt., s. 356.

${ }^{57}$ M. Starnawska, Krucjata i Ziemia Święta..., dz. cyt., s. 167-179; zob. M. Starnawska, Między Jerozolima a Łukowem..., dz. cyt., s. 172 oraz R. Skrzyniarz, Kanonicy Grobu Bożego..., dz. cyt., s. 357.

${ }^{58}$ Skaryszew już w momencie nadania go bożogrobcom przez komesa Radosława posiadał zarówno kościół, jak i targ, KMp 2, nr 375-6. W dokumencie króla Władysława Jagiełły z 1432 roku czytamy o zatwierdzeniu jednego z jarmarków w Skaryszewie „in festo s. Jacobi”, Zbiór dokumentów małopolskich. Dokumenty króla Władysława Jagiełly z lat 1418-1434, cz. 7, wyd. I. Sułkowska-Kuraś i S. Kuraś, Wrocław 1975, nr 2112. Wydawca nie miał wątpliwości, że chodziło o dzień 25 lipca, a zatem w święto św. Jakuba Starszego. Dalszym badaniom powinny zostać poddane źródła nowożytne, w tym także zapisy o jarmarkach skaryszewskich (skądinąd słynnych), gdyż ich datacja dzienna może rzucić pewne światło na kwestię wezwania.

${ }_{59} \mathrm{Dlb}$ 2, s. 113; w Dlb 3, s. 9 nie podał wezwania.

${ }^{60}$ KMp. 2, nr 376.

${ }^{61}$ S. Nakielski, Miechovia..., dz. cyt., s. 388. Wiadomość o wystawieniu nowego kościoła podaje pod rokiem 1412 „Rocznik miechowski”, s. 125.

${ }^{62}$ Dokument ten w całości zamieszcza S. Nakielski, Miechovia..., dz. cyt., s. 547. 
inne wezwania w tytule tego kościoła. Wezwanie jest typowe dla wielu starych świątyń w Małopolsce, a kult św. Jana Chrzciciela, widoczny u bożogrobców, występuje także w innych zakonach ${ }^{63}$.

W XIII wieku pod administracją bożogrobców miechowskich znalazł się kościół parafialny w Uniejowie, wsi położonej koło Skały ${ }^{64}$, będący fundacją rycerskich właścicieli wsi. Zachowały się 2 dokumenty prepozyta Marcina Czcika z 1373 i 1375 roku, w których czytamy o dokonanym przez prepozyta uposażeniu kościoła w Uniejowie. Jest w nich odnotowane wezwanie św. Wita ${ }^{65}$. Dzieło Długosza i wizytacja z końca XVI wieku również notują to wezwanie ${ }^{66}$, a S. Nakielski wypowiada się o nim jako o „pradawnym kościele św. Wita”67.

Możemy zatem wykazać, że bożogrobcy posiadali, w pierwszym wieku po powstaniu klasztoru, 4 kościoły (Miechów, Skaryszew, Chełm, Uniejów). O wpływie zakonu na dobór wezwania nie może być wątpliwości w przypadku kościoła klasztornego w Miechowie. Nie można wykluczyć, że kościoły św. Jakuba w Skaryszewie i św. Jana w Chełmie zostały ufundowane dla klasztoru miechowskiego. Pewne przykłady wskazują, że nawet przejmując istniejący kościół bożogrobcy mieli możliwości wpływu na propagowanie określonego świętego uwiecznionego w wezwaniu głównym, względnie na jakąś zmianę w dedykacji. Tak mogło być w przypadku kościoła w Skaryszewie.

Znakomitym przykładem jest kościół w Chodowie. Zachował się dokument biskupa krakowskiego Zawiszy z Kurozwęk z 1381 roku, w który stwierdza on, że erygował parafię chodowską i uposażył dziesięcinami ufundowany przez siebie tamtejszy kościół pw. N. Marii Panny i św. Jana Ewangelisty ${ }^{68}$. W 1404 roku bożogrobcy kupili od szlachty tę wieś wraz z kościołem. „Rocznik miechowski” odnotował w 1404 roku, czyli w roku przejęcia kościoła przez kanoników, jego konsekrację pw. Nawiedzenia N. Maryi Panny, św. Jana Chrzciciela, św. Jana Ewangelisty i św. Małgorzaty. Przyczyny powtórnej konsekracji nie są znane ${ }^{69}$. Niezbędne jest w tym miejscu podkreślenie, że kościół w Chodowie stanowi

${ }^{63}$ O kulcie tym u bożogrobców pisał F. Wolnik, Święci w zabytkach liturgicznych..., dz. cyt., s. 160 .

${ }^{64}$ Klasztor uzyskał tę wieś w pierwszej połowie XIII w., KMp. 2, $\mathrm{nr} 397$.

${ }^{65}$ KMp. 3, nr 858 i 879; S. Nakielski, Miechovia..., dz. cyt., s. 300-302.

${ }^{66} \mathrm{Dlb} 3$, AKM, AVcap 15 k. 41v- 42v.

${ }^{67}$ S. Nakielski, Miechovia..., dz. cyt., s. 131.

${ }^{68}$ KMp. 3, nr 922.

${ }^{69}$ „Rocznik miechowski”, dz. cyt., s. 131. O przyczynach powtórnych konsekracji pisali P. Sczaniecki, Sacramentum dedicationis..., dz. cyt., s. 67 i I. Skierska, Obowiązek mszalny w średniowiecznej Polsce, Warszawa 2003, s. $69 n$. 
jeden z najstarszych przykładów pojawienia się przy wezwaniu maryjnym atrybucji, w tym przypadku w postaci wezwania Nawiedzenia ${ }^{70}$, co świadczy o rozbudowanym kulcie maryjnym w zakonie bożogrobców ${ }^{71}$. Faktem jest także, że bożogrobcy dodali do istniejącego już od 1381 roku tytułu, dwóch świętych, a mianowicie św. Jana Chrzciciela i św. Małgorzatę. Świadczy to o promowaniu kultu tych świętych. Zapiski takie, jak w przypadku Chodowa, należą do rzadkości, a ich wartość jest bezcenna. Ujawniają zarówno złożoność wezwania, jak i ukazują pojawianie się za sprawą zakonników nowych kultów, uniwersalnych dla duchowości chrześcijańskiej. W opisie Długosza kościół chodowski figuruje tylko z patrocinium św. Jana Chrzciciela, co nie oddaje zjawiska złożoności tej dedykacji. Jednak wskazuje ono, że za sprawą bożogrobców mogło dojść do wysunięcia wezwania św. Jana Chrzciciela przed inne, w tym, co ciekawe, przed maryjne. Nakielski również powołuje się na tę zapiskę z 1404 roku, ale zaznacza, że zaczerpnął ją „ex vetusto Codice Conventuali”. Kanonik wspominał o konsekracji kościoła w Chodowie z wezwaniem Jana Chrzciciela, Jana Ewangelisty i św. Małgorzaty ${ }^{72}$. Niewątpliwie dotyczy to konsekracji odnotowanej przez „Rocznik miechowski”. Nakielski, jak łatwo zauważyć, pomija patrocinium Nawiedzenia N. Marii Panny. Różnice te mogą wynikać, jak wskazują liczne inne przykłady $\mathrm{w}$ badaniach nad patrociniami, $\mathrm{z}$ celowego lub nieumyślnego pomijania poszczególnych składników tytułu kościoła.

Szczególne miejsce na mapie religijnego oddziaływania bożogrobców zajmowała nieistniejąca już świątynia na Stradomiu, u stóp wzgórza wawelskiego. Król Kazimierz Wielki rozpoczął budowę kościoła i szpitala dedykowanego św. Elżbiecie i św. Jadwidze. Z woli królowej Elżbiety, żony Ludwika Węgierskiego, nieukończony kościół stradomski został w 1375 roku przekazany bożogrobcom

${ }^{70}$ Potwierdzeniem tej tezy jest także wezwanie kościoła w Żarnowcu, gdzie występuje patrocinium Nawiedzenia N. Marii Panny („Rocznik miechowski”, s. 131 pod rokiem 1404). Atrybuty N. Marii Panny pojawiają się znacznie wcześniej, niż te, które opisywał W. Rozynkowski, Wezwania kościołów..., dz. cyt., s. 252. Badacz ten uważa, że atrybucje przy wezwaniu maryjnym pojawiają się dopiero w późnym średniowieczu. Do najstarszych przykładów należy, jego zdaniem, relacja Długosza o kościele kanoników w Kurozwękach.

${ }^{71}$ Tego ważnego wątku nie mogę tu z braku miejsca rozwijać, ostatnio na ten temat pisze R. Skrzyniarz, Kanonicy Grobu Bożego..., dz. cyt., s. 356; zob. także F. Wolnik, Święci w zabytkach liturgicznych..., dz. cyt., s. 157; w 1439 roku klasztor miechowski otrzymał odpusty na święto Niepokalanego Poczęcia, zob. P. Kardyś, Średniowieczne dyplomy pergaminowe bożogrobców z Miechowa $w$ Archiwum Diecezjalnym w Kielcach, [w:] Rycerze, wędrowcy, kacerze. Studia $z$ historii średniowiecznej i wczesnonowożytnej Europy Środkowej, red. B. Wojciechowska, W. Kowalski, Kielce 2013, s. 182.

${ }^{72}$ S. Nakielski, Miechovia..., dz. cyt., s. 320. 
z zaleceniem, aby z własnych środków budowę tę ukończyli. Funkcjonujący zatem w Xv wieku kościół i szpital na Stradomiu były dziełem zakonników, ale nie mieli chyba żadnego wpływu na to, że kościół ten nosił wezwanie św. Elżbiety i św. Jadwigi. Niezwykle liczne informacje źródłowe z Xv-Xvi wieku wskazują, co godne uwagi, na używanie wyłącznie patrocinium św. Jadwigi. Można twierdzić zatem, że to za sprawą bożogrobców rozpropagowane zostało wezwanie św. Jadwigi, przy całkowitym pominięciu pierwszego wezwania św. Elżbiety ${ }^{73}$. Był to zabieg celowy, bowiem dla propagowania drugiego kultu wystarczyło, aby w dokumentach bożogrobców wymieniano także patrocinium św. Elżbiety. Kościół ten miał wyjątkowe znaczenie dla promowania kultu św. Jadwigi Śląskiej"

Kościół szpitalny w Żarnowcu, miasteczku królewskim położonym na północ od Miechowa, również jest przykładem złożonego wezwania głównego. Ujawnia ponadto zastosowanie dedykacji, którą znamy już z analizy wezwań kościoła w Miechowie. Fundację żarnowieckiej kaplicy i szpitala zapoczątkował w 1404 roku Michał Trestka, ale przejąl ją król Władysław Jagiełło, który w tymże roku przekazał szpital bożogrobcom ${ }^{75}$. Gdy w 1404 roku Piotr Wysz, biskup krakowski, erygował kaplicę szpitalną w Żarnowcu pw. Znalezienia Krzyża Świętego i Podwyższenia Krzyża Świętego, stwierdzał, że uczynił to na prośbę bożogrobców miechowskich $^{76}$. Wskazuje to, że kanonicy mieli wpływ na fundację i dobór wezwania. „Rocznik miechowski” posiadał dane o konsekracji nieznane innym

${ }^{73} \mathrm{O}$ szpitalach prowadzonych przez bożogrobców miechowskich syntetyczne zestawienie dała M. Starnawska, Działalność szpitalna zakonów krzyżowych w miastach średniowiecznych na ziemiach polskich, [w:] Klasztor $w$ mieście średniowiecznym i nowożytnym, red. M. Derwich, A. Pobóg-Lenartowicz, Wrocław-Opole 2010, s. 267. Autorka nie zajmowała się kwestią ich wezwań. W. Rozynkowski, Wezwania kościołów..., dz. cyt., s. 253, notuje jeden przykład wezwania św. Jadwigi (Zielona Góra), którą uważa za rzadką patronkę kościołów zakonnych.

${ }^{74}$ J. Rajman, Exemplaris tu columpna. Z problematyki kultu świętej Jadwigi Ślaskiej $w$ średniowiecznej Małopolsce, [w:] Memoria viva. Studia historyczne poświęcone pamięci Izabeli Skierskiej (1967-2014), red. G. Rutkowska, A. Gąsiorowski, Warszawa-Poznań 2015, s. 175-19o. F. Wolnik, Święci w zabytkach liturgicznych..., dz. cyt., s. 159 stwierdza, że św. Jadwiga Śląska miała w kalendarzu nyskich bożogrobców rangę „duplex”, co dowodzi wysokiej rangi tego kultu.

75 „Rocznik miechowski”, dz. cyt., s. 131; Zbiór dokumentów małopolskich, cz. 6, wyd. I. Sułkowska-Kuraś i S. Kuraś, Wrocław 1974, nr 1664; M. Starnawska, Między Łukowem a Jerozolima. Zakony krzyżowe na ziemiach polskich w średniowieczu, Warszawa 2006, s. 85, 357.

${ }^{76}$ Zbiór dokumentów katedry i diecezji krakowskiej, 1-2, wyd. S. Kuraś, Lublin 1965-73 [dalej: zDK], cz. 1, nr 162; dokument ten cytuje S. Nakielski, Miechovia..., dz. cyt., s. 375; o rozwoju patrociniów Krzyża św. wypowiadała się M. Starnawska, Świętych życie po życiu, s. 105 (tam też starsza literatura), słusznie stwierdzając, że zagadnienie to wymaga pogłębionych badań. O kulcie Krzyża św. zob. w tym artykule przypis 28; zob. także A. Szymański, Patrocinia Krzyża Świętego w Polsce, „Studia Teologiczno-Historyczne Śląska Opolskiego” 27 (2007), s. 137-156. 
źródłom. Podał mianowicie pod rokiem 1404, że kościółek szpitalny w Żarnowcu otrzymał przy konsekracji wezwania: Znalezienia Krzyża Świętego, Podwyższenia Krzyża Świętego, Grobu Pańskiego i Nawiedzenia N. Maryi Panny ${ }^{77}$. Z 1422 roku zachowała się wiadomość o wezwaniu Ducha Świętego, jakie nosił szpital ${ }^{78}$. $\mathrm{W}$ dokumencie z 1425 roku wymieniono osobno wezwanie Ducha Świętego jako wezwanie szpitala i wezwanie Krzyża św. jako wezwanie kościoła w Żarnowcu ${ }^{79}$. W 1426 roku pisze się tylko o wezwaniu Krzyża św. ${ }^{80}$. Gdy kardynał Fryderyk Jagiellończyk nadawał w 1489 roku kaplicy żarnowieckiej odpusty, wspomniano, że ma ona wezwanie Krzyża św. i Ducha Świętego ${ }^{81}$. Należy podkreślić złożoność i wyjątkowość dedykacji kościoła żarnowieckiego, a zwłaszcza obecność ekskluzywnego patrocinium Grobu Pańskiego. Warto zauważyć, że zestawienie patrociniów Grobu Bożego, N. Marii Panny i Ducha Świętego jest powtórzeniem dedykacji występującej w kościele miechowskim, co wskazuje na wielkie znaczenie, jakie bożogrobcy przywiązywali od samego początku do fundacji żarnowieckiej. Jest to niewątpliwie także wyraz wspólnoty duchowej z monarchą. Wezwanie Krzyża św. kościoła w Żarnowcu łatwo wytłumaczyć silnym, zarówno u króla Władysława Jagiełły, jak i w zakonie bożogrobców, kultem Krzyża Świętego ${ }^{82}$. Intencje fundatora i zakonu były całkowicie zgodne, jest to zarazem najwcześniejsze poświadczenie wezwania Krzyża Świętego w kościele związanym $\mathrm{z}$ bożogrobcami w Małopolsce.

Kult Krzyża Świętego bożogrobcy rozwijali także, a może przede wszystkim, w Miechowie. Przypomnieć tu należy, że w kościele miechowskim prawdopodobnie znajdowała się relikwia Krzyża Pańskiego. Kanonicy byli fundatorami kaplicy we wsi Siedliska, położonej ok. $2 \mathrm{~km}$ od Miechowa. Kaplica ta jest poświadczona pw. Krzyża Świętego w 1504 roku przy okazji wystawienia przywileju odpustowego $^{8_{3}}$. Wezwanie to wywarło wpływ na nazewnictwo, gdyż w 1559 roku drogę łączącą tę kaplicę z miastem nazywano „ulicą św. Krzyża” ${ }^{84}$.

77 „Rocznik miechowski”, dz. cyt., s. 131; powtórzył to S. Nakielski, Miechovia..., dz. cyt., s. 379.

${ }^{78}$ S. Nakielski, Miechovia..., dz. cyt., s. 413. Wezwanie Ducha św. występuje także w kościołach bożogrobców poza Małopolską, np. w Kole, Rypinie, Przeworsku, pod Sieradzem i pod Bytomiem, ale analizę tych patrociniów pozostawiam do odrębnego opracowania.

79 S. Nakielski, Miechovia..., dz. cyt., s. 414.

${ }^{80}$ S. Nakielski, Miechovia..., dz. cyt., s. 421-422.

${ }^{81}$ S. Nakielski, Miechovia..., dz. cyt., s. 554.

${ }^{82}$ Zob. wyżej przypisy 28 i 31 oraz odpowiadający im tekst.

${ }^{83}$ S. Nakielski, Miechovia..., dz. cyt., s. 573.

${ }^{84}$ Księga sądu ławniczego w Miechowie $z$ lat $1558-1565$, k. 76 . Rękopis ten jest obecnie przechowywany w Miejskiej Bibliotece Publicznej w Miechowie. 
Z woli bożogrobców, ale zapewne przy finansowym udziale mieszczan, powstała w Miechowie kaplica szpitalna św. Barbary. Nie posiada ona dostatecznej dokumentacji źródłowej dla epoki średniowiecza. Wiadomo tylko, że szpital miechowski jest poświadczony w 1449 roku $^{85}$. Można na tej podstawie przypuszczać, że w xv wieku powstała kaplica szpitalna św. Barbary, ale jej wezwanie odnotowano po raz pierwszy w 1560 roku $^{86}$. Nakielski podaje pod rokiem 1626, że w miejscu drewnianej kaplicy św. Barbary powstała budowla murowana ${ }^{87}$.

W 1394 roku biskupstwo lubuskie sprzedało bożogrobcom wieś Wrocieryż (koło Pińczowa) wraz z kościołem. Wezwania tego kościoła wówczas nie podano, co ciekawe, nie notuje go ani Długosz, ani wizytatorzy kardynała Radziwiłła ${ }^{88}$. Jest to jedyny kościół bożogrobców nieposiadający odpowiedniej dokumentacji. Nakielski twierdził, że bożogrobcy kupili wieś wraz z kościołem św. Marcina ${ }^{89}$. Godne podkreślenia jest, że kronikarz klasztorny sięgnął do materiałów przechowywanych w parafii Wrocieryż, z których odpisał, że kościół we Wrocieryżu został konsekrowany na nowo w 1448 roku ${ }^{90}$, a więc już za sprawą bożogrobców. Z jego dzieła dowiadujemy się również o istniejącym tam złożonym wezwaniu w 1546 roku wymieniono bowiem w dedykacji: N. Marię Pannę, św. św. Marcina, Stanisława, Wacława, Floriana, Wojciecha, Wawrzyńca, Wszystkich Apostołów i Ewangelistów, a także święte Dziewice, Katarzynę, Barbarę, Małgorzatę i Dorotę ${ }^{91}$.

Przed 1410 rokiem bożogrobcy uzyskali częściowe prawo patronatu do kościoła w Sławicach, koło Miechowa ${ }^{92}$. Z dzieła Długosza i późniejszych źródeł wiadomo, że kościół ten nosił wezwanie św. Wojciecha ${ }^{93}$. Pod 1416 rokiem Nakielski odnotował uzyskanie prawa patronatu kościoła w Tarnowie w dekanacie jędrzejowskim i na poparcie tej informacji zacytował dokument biskupa Wojciecha Jastrzębca $\mathrm{z}$ tego roku ${ }^{94}$. Jednak nie ma w nim wzmianki o wezwaniu. Nakielski pisał, że był

${ }^{85}$ Acta Officialatus Cracoviensis, 1, AKM, s. 134.

${ }^{86}$ Księga sądu ławniczego, k. 121; L. Wojciechowski, Parafia $w$ Miechowie $w$ okresie przedrozbiorowym, [w:] Bożogrobcy w Miechowie, red. M. Affek, Warszawa 1999, s. 74 intuicyjnie datuje wzniesienie kaplicy św. Barbary na Xvi wiek.

${ }^{87}$ S. Nakielski, Miechovia..., dz. cyt., s. 908.

${ }^{88}$ Dlb 3, s. 15-16, AKM, AVCap 10, k. 84v.

${ }^{89}$ S. Nakielski, Miechovia..., dz. cyt., s. 349 .

${ }^{90}$ S. Nakielski, Miechovia..., dz. cyt., s. 350 .

${ }^{91}$ S. Nakielski, Miechovia..., dz. cyt., s. 350.

${ }_{92}$ ZDK 1, nr 181, S. Nakielski, Miechovia..., dz. cyt., s. 383 cytuje dokument sądu ziemskiego krakowskiego z 1410 roku o kupnie przez klasztor wsi Parkoszowice wraz z prawem patronatu kościoła w Sławicach.

${ }^{93}$ DLb 2, s. 50-51; AVcap 10, k. 132.

${ }^{94}$ S. Nakielski, Miechovia..., dz. cyt., s. 395-6, 481 (o patronacie do kościoła w Tarnowie). 
to kościół pw. Narodzenia N. Marii Panny. Klasztor bożogrobców uzyskał także prawo patronatu do kościoła we Wrocimowicach i w Racławicach ${ }^{95}$. Nakielski podaje o Wrocimowicach, że kościół św. Andrzeja został zbudowany w 1410 roku $^{96}$. Wezwanie św. Andrzeja we Wrocimowicach, a św. św. Piotra i Pawła w pobliskich Racławicach poświadcza także Jan Długosz i protokół powizytacyjny z końca XVI wieku' ${ }^{97}$.

Mało zbadanym zagadnieniem są wezwania wewnętrzne, czyli wezwania kaplic znajdujących się w obrębie kościoła i wezwania ołtarzy. Szczególnie bogatych i wczesnych przykładów dostarcza kościół Grobu Pańskiego w Miechowie. Nie ulega wątpliwości, że w tym przypadku zakon bożogrobców miał szczególne kompetencje do kształtowania programu religijnego przestrzeni kościelnej. Zachowały się wyjątkowo wczesne i wyjątkowo dokładne informacje o wezwaniach wewnętrznych kościoła miechowskiego, dzięki temu możemy postawić tezę, że pierwsze ołtarze w kościele bożogrobców powstały nie później, niż w pierwszej połowie XIV wieku. Można stwierdzić, że najstarsze wezwania wewnętrzne w kościele miechowskim to patrocinium Grobu Bożego, jakie nosił ołtarz główny, a także św. Katarzyny, związane z kaplicą. W zapisce „Rocznika miechowskiego” z 1348 roku podano, że ołtarz główny kościoła miechowskiego został konsekrowany w 1348 roku pw. Grobu Świętego ${ }^{98}$. O ołtarzu głównym pisał także S. Nakielski, tytułując go wezwaniem Grobu Pańskiego i św. Jakuba Mniejszego. Twierdził, że informacje te odnalazł ,in vetusto codice manuscripto”. Jego przekaz jest najstarszym świadectwem istnienia w kościele miechowskim wezwania nawiązującego do pierwszego biskupa Jerozolimy ${ }^{99}$. Kaplica św. Katarzyny również została poświadczona w zapisce rocznikarskiej z 1348 roku $^{100}$, co w pewnym stopniu uwiarygodnia przekaz S. Nakielskiego, który pisał, że po wybudowaniu drugiego kościoła miechowskiego (konsekrowanego przez biskupa Wisława), stary kościółek został zamieniony na kaplicę („sacellum”) św. Katarzyny ${ }^{101}$. Zapiska

95 Patronat poświadczony w 1598 roku, AKM, AVCap 10, k. 141 i 143.

${ }^{96}$ S. Nakielski, Miechovia..., dz. cyt., s. 773-774.

97 Dlb 1, s. 98, 119; AKM, AVCap 10, k. 141, 143.

${ }_{98}$ „Rocznik miechowski”, dz. cyt., s. 125; o ołtarzach Grobu Pańskiego zob. J. E. A., Kroesen, The Sepulchrum Domini..., dz. cyt., s. 56.

${ }^{99}$ S. Nakielski, Miechovia..., dz. cyt., s. 266. Być może na podstawie tej relacji pojawił się w literaturze pogląd (zob. wyżej przypis 50), że kościół miechowski miał wezwanie Grobu Pańskiego i św. Jakuba Mniejszego. Należy podkreślić, że jest to wezwanie ołtarza głównego, a nie kościoła. O kontrowersjach związanych z patrocinium św. Jakuba w Skaryszewie zob. w tym artykule przypisy 55-58 i odpowiadający im tekst.

${ }_{100}$ „Rocznik miechowski”, dz. cyt., s. 125.

${ }^{101}$ S. Nakielski, Miechovia..., dz. cyt., s. 64, 81 . 
z 1348 roku podaje informacje o jeszcze trzech innych ołtarzach, a mianowicie św. Jakuba Apostoła, którego usytuowania nie podano, św. Mikołaja, również bez lokalizacji oraz ołtarza w kaplicy św. Katarzyny, o którego wezwaniu poskąpiono wzmianki ${ }^{102}$. O tych ołtarzach, w nawiązaniu do konsekracji z 1348 roku, pisał także S. Nakielski, powołując się znów na wzmianki „in vetusto codice manuscripto”. Ołtarz św. Mikołaja określa jako „inferius” (na niższym miejscu?) i podaje, że w jego czasach został przeniesiony w inne miejsce. Pisał także o konsekracji ołtarza św. Katarzyny, usytuowanego w zakrystii, przeniesionego później do kaplicy $^{103}$. Nie trudno zauważyć, że Nakielski pominął ołtarz św. Jakuba Apostoła, co byłoby trudne do zrozumienia, gdyby swą relację opierał na jasno brzmiącym przekazie „Rocznika miechowskiego”. Niewątpliwie opierał się na innym źródle.

Dalszych wzmianek o ołtarzach i kaplicach w kościele miechowskim z tego okresu brak. Kolejne pochodzą z przełomu xıv/xv wieku. Autor „Rocznika miechowskiego", opisując budowę nowego kościoła rozpoczętą przez prepozyta Michała z Radomska, wymienił 2 nowe kaplice i aż 6 ołtarzy, nie skąpiąc przy tym informacji o wezwaniach ${ }^{104}$. Kaplica w kościele miechowskim, usytuowana „pod schodami”, została w 1404 roku dedykowana św. Michałowi Archaniołowi, św. Filipowi Apostołowi i św. Dorocie. Nakielski również cytuje tę zapiskę i podaje, że kaplica pod schodami otrzymała wezwanie Grobu Pańskiego, św. Michała Archanioła i Wszystkich Aniołów, Apostołów Filipa i Jakuba oraz św. Doroty ${ }^{105}$. Nie wydaje się, aby dodając patrocinium Grobu Pańskiego i św. Jakuba Mniejszego dokonał samowolnego rozszerzenia relacji rocznika. Wchodzi w grę, jak sądzimy, korzystanie z źródła innego, niż znany nam „Rocznik miechowski”. Według tegoż rocznika, w kaplicy tej znajdowały się dwa ołtarze, a z kontekstu zapiski można wnioskować, że jeden był dedykowany św. Michałowi, drugi zaś św. Filipowi i św. Dorocie ${ }^{106}$. Należy zauważyć, iż „Rocznik miechowski” dwukrotnie wymienił wezwanie św. Filipa, raz jako kaplicy, drugi raz jako ołtarza w tej kaplicy. Co charakterystyczne, w roczniku nie podano wezwania św. Jakuba Mniejszego (najczęściej występującego właśnie razem z św. Filipem). Św. Jakub Mniejszy pojawił się natomiast dopiero w relacji Nakielskiego.

102 „Rocznik miechowski”, dz. cyt., s. 125.

${ }^{103}$ S. Nakielski, Miechovia..., dz. cyt., s. 266.

104 „Rocznik miechowski”, dz. cyt., s. 131; por. P. Pencakowski, Przemiany formy i funkcji wieży kościoła parafialnego (dawniej bożogrobców) w Miechowie, „Kwartalnik Architektury i Urbanistyki” 36 (1991) z. 3, s. 216.

${ }^{105}$ S. Nakielski, Miechovia..., dz. cyt., s. 381.

${ }^{106}$ „Rocznik miechowski”, dz. cyt., s. 131. Święto konsekracji tej kaplicy miało być obchodzone w pierwszą niedzielę po święcie św. Gawła. 
Jak pokażemy na przykładzie ołtarza miechowskiego pw. św. Jakuba Większego, istnienie ołtarza św. Jakuba Mniejszego jest w kościele miechowskim wysoce prawdopodobne. Według „Rocznika miechowskiego” druga kaplica, umieszczona w przyziemiu wieży, została konsekrowana w 1408 roku pw. Grobu Bożego, św. Łazarza, św. Marty i św. Marii Magdaleny ${ }^{107}$.

Bardzo ciekawe i charakterystyczne są wezwania kaplicy w przyziemiu wieży kościoła miechowskiego. Powtórzono w niej wezwanie główne, a więc patrocinium Grobu Pańskiego, ale dodano także wezwania świętych kojarzące się mocno z ostatnimi dniami życia Pana Jezusa w Jerozolimie. Umieszczenie w jednej dedykacji wezwań Grobu Bożego, św. Łazarza, św. Marty i św. Marii Magdaleny tworzyło jasny przekaz skierowany do wiernych i przypominało o najważniejszym przesłaniu Nowego Testamentu. Na szczególne podkreślenie zasługuje patrocinium św. Marii Magdaleny, zarówno w kontekście nawiązania do motywu nawiedzenia Grobu, jak też jako wyraz silnego kultu tej świętej u bożogrobców. Jej święto przypadałona 22 lipca, czyli w oktawie niezwykle ważnego dla bożogrobców święta konsekracji Bazyliki Grobu Pańskiego w Jerozolimie ${ }^{108}$. Święto to przypadało na dzień 15 lipca, w którym upamiętniano uroczystymi procesjami w Jerozolimie zdobycie miasta przez krzyżowców w 1099 roku $^{109}$. Na ten dzień przypada, jak wiadomo, święto Rozesłania Apostołów. Zdaniem S. Nakielskiego, konsekrację kościoła miechowskiego również obchodzono w dniu 15 lipca ${ }^{110}$. Na przeprowadzanym etapie badań nie napotkałem na ślad patrocinium Rozesłania Apostołów w kościele miechowskim, ale istnienie ołtarza pod tym wezwaniem jest wysoce prawdopodobne. Wskazuje na to wielkie znaczenie obchodów w dniu 15 lipca, jak również analogia do kościoła bożogrobców na Stradomiu, gdzie wezwanie to jest poświadczone ${ }^{111}$.

107 „Rocznik miechowski”, dz. cyt., s. 131; takie same wezwania podał S. Nakielski, Miechovia..., dz. cyt., s. 381 .

${ }^{108}$ F. Wolnik, Tajemnica Krzyża w liturgii nyskich bożogrobców, „Studia Teologiczno-Historyczne Śląska Opolskiego" 16 (1996), s. 310-312.

${ }^{109}$ M. Starnawska, Grunwald, Jerozolima i święto Rozesłania Apostołów, [w:] Conflictus magnus apud Grunwald 1420. Między historia a tradycją, red. K. Ożóg, J. Trupinda, Malbork 2013, s. 222. Badaczka ta dopuszcza możliwość, że procesje jerozolimskie mogły, za pośrednictwem bożogrobców, wpłynąć na kształt obchodów rocznicy zwycięstwa pod Grunwaldem; podobnie wypowiada się R. Skrzyniarz, Kanonicy Grobu Bożego..., dz. cyt., s. 339, który dopuszcza, że kanonikom „powierzono uroczyste świętowanie”.

${ }^{110}$ R. Skrzyniarz, Kanonicy Grobu Bożego..., dz. cyt., s. 339, tam dokumentacja źródłowa.

${ }^{111}$ Zob. w tym artykule przypis 133 i odpowiadający mu tekst. Wezwanie „Rozesłania Apostołów” nosił, leżący poza Małopolską, kościół w Łęgonicach, ufundowany przez biskupa Mikołaja Trąbę i oddany bożogrobcom, zob. M. Starnawska, Grunwald, Jerozolima..., dz. cyt., s. 225. 
Na podstawie „Rocznika miechowskiego” można także zidentyfikować ołtarze niezwiązane z kaplicami. Ołtarz św. Augustyna i Wszystkich Świętych Doktorów Kościoła, świętych dziewic Agnieszki i Barbary oraz świętych męczenników został wymieniony przy okazji wzmianki w 1404 roku o konsekracji kaplicy „pod schodami”. Został konsekrowany w tym samym roku, ale jego usytuowanie nie jest znane ${ }^{112}$. Porównując ten przekaz z relacją Nakielskiego, znów dostrzegamy istotną różnicę. Według „Rocznika miechowskiego” był to jeden ołtarz z zbiorowym wezwaniem, natomiast historyk zakonu podaje, że ad haec były dwa ołtarze, pierwszy św. Augustyna „patriarchae ordinis nostri”, oraz drugi, dedykowany św. św. Agnieszce i Barbarze, Dziewicom i Męczenniczkom ${ }^{113}$. Wymienia więc te same wezwania, co „Rocznik miechowski”, ale rozdzielone między dwa ołtarze. Warto podkreślić istnienie ołtarza św. Augustyna, czczonego u bożogrobców (oraz w całym kanonikacie) jako twórca reguły zakonnej ${ }^{114}$.

W 1408 roku wzmiankowany jest ołtarz w nawie kościoła „od strony domu, czyli dworu”. Ołtarz ten stał w nawie kościoła po lewej stronie (od strony klasztoru). Miał on wezwanie „św. Jakuba Większego, św. Jana Ewangelisty oraz wszystkich Apostołów i Ewangelistów" ${ }^{115}$. Podajemy tu wiernie całe brzmienie dedykacji, gdyż kryje ona bardzo ważną informację. Jeśli bowiem autor „Rocznika miechowskiego" odnosił swój opis do znanego sobie wnętrza kościoła, to określenie „św. Jakub Większy” miało sens, gdy istniał także ołtarz św. Jakuba Mniejszego. Patrocinium pierwszego biskupa Jerozolimy jest wzmiankowane, jak już wspominaliśmy, tylko u Nakielskiego. Jego przekaz, oparty zapewne o źródło inne, niż nasz „Rocznik miechowski”" ${ }^{116}$, niewątpliwie zasługuje na uznanie.

Odniesiemy się znów do analizy zapisek w „Roczniku miechowskim”. Źródło to podaje, że „od strony miasta”, a więc po prawej stronie nawy, ustawiono ołtarz dedykowany św. Mikołajowi i św. Marcinowi oraz „wszystkim świętym biskupom i wyznawcom" ${ }^{117}$. Ołtarz św. Mikołaja był wzmiankowany, jak wspominaliśmy, już w 1348 roku. Dodać jeszcze należy informację zaczerpniętą z dzieła S. Nakielskiego, że w 1448 roku Mikołaj Pieniążek z Witowic ofiarował klasztorowi miechowskiemu dziesięcinę $\mathrm{z}$ ról folwarcznych w Witowicach, a w zamian zamówił msze wieczyste. Msza za odpuszczenie grzechów, która ma być odprawiana przy

112 „Rocznik miechowski”, dz. cyt., s. 131.

${ }^{113}$ S. Nakielski, Miechovia..., dz. cyt., s. 381.

${ }^{114}$ F. Wolnik, Święci w zabytkach liturgicznych..., dz. cyt., s. 158; R. Skrzyniarz, Kanonicy Grobu Bożego..., dz. cyt., s. 357 .

${ }^{115}$ „Rocznik miechowski”, dz. cyt., s. 131-132.

${ }_{116}$ Zob. A. Chojnacki, Dwie wersje „Rocznika miechowskiego”..., dz. cyt., s. 57-71.

${ }^{117}$ „Rocznik miechowski”, s. 132; tak samo S. Nakielski, Miechovia..., dz. cyt., s. 381. 
nowym ołtarzu koło hostii. Podano nawet, że ołtarz ten jest od strony cmen$\operatorname{tarza}^{118}$. Można przypuszczać, że chodzi tu o wspomniany ołtarz św. Mikołaja, na co wskazuje zarówno usytuowanie, jak i imię tego, który zamawiał msze (przy założeniu, że czcił swojego patrona).

Pod 1592 rokiem wspomina się o ołtarzu głównym kościoła miechowskiego, niestety nie podając wezwania ${ }^{119}$, ale niewątpliwie dedykowany był Grobowi Bożemu. O miejscu pochowania Pana Jezusa w Jerozolimie przypominała przede wszystkim kaplica Grobu Bożego wybudowana w 1534 roku przy krużganku klasztornym $^{120}$. Dodać należy, że znany był jeden z relikwiarzy, które w 1584 roku otrzymał Andrzej Batory, a mianowicie „relikwiarz w kształcie kaplicy Grobu Chrystusa w Jerozolimie"121.

$Z$ faktu istnienia bractwa św. Anny w kościele miechowskim, wzmiankowanego już w 1516 roku $^{122}$, wnioskować można o ołtarzu pod tym wezwaniem. Możemy domyślać się także ołtarzowego wezwania św. Krzyża, pośrednią przesłankę daje wzmianka o bractwie Męki Pańskiej w Miechowie z 1610 roku $^{123}$.

W ołtarzach tych znajdowały się relikwie, o czym przekonuje analogia do kościoła stradomskiego ${ }^{124}$. Owa druga wzmiankowana przez Nakielskiego stara relikwia ${ }^{125}$, to partykuła ręki świętego określonego jako „sancti Viti” ${ }^{126}$, czyli zapewne św. Wita. Kronikarz podał, że w 1584 roku prepozyt Andrzej Batory sprowadził do Miechowa liczne relikwie świętych („in ecclesiam importate”), a mianowicie świętych: Barnaby, Sebastiana, Maksyma Męczennika, Simpliciusza Wyznawcy,

${ }^{118}$ S. Nakielski, Miechovia..., dz. cyt., s. 488.

${ }_{119}$ S. Nakielski, Miechovia..., dz. cyt., s. 770.

${ }^{120}$ J. Z. Łoziński, Miechowskie Sepulchrum Domini, „Biuletyn Historii Sztuki” 31 (1969), s. 151, 164; T. Chrzanowski, M. Kornecki, Sztuka ziemi krakowskiej, Kraków 1982, s. 203-204. Kaplica miechowska powinna wreszcie doczekać się nowoczesnych badań archeologiczno-architektonicznych. Można w tym miejscu, bez rozwijania wątku, zasygnalizować ważne uwagi w pracy J. E. A. Kroesen, The Sepulchrum Domini..., dz. cyt., s. 45.

${ }^{121}$ Katalog zabytków sztuki, t. 1, dz. cyt., s. 233.

${ }^{122}$ AKM, Acta Officialatus Cracoviensis, t. 38, s. 90 (zapiskę tę wskazał mi ks. prof. Andrzej Bruździński, za co składam serdeczne podziękowanie). O bractwie tym pisze L. Wojciechowski, Parafia $w$ Miechowie $w$ okresie przedrozbiorowym..., dz. cyt., s. 76 jako erygowanym w 1602 roku, co wymaga, rzecz jasna, korekty w świetle zapiski z 1516 roku. Autor ten podaje również, że najstarsze polskie bractwo św. Anny zostało erygowane w 1578 roku. Nie trudno zauważyć, że w tym kontekście bractwo miechowskie jawi się jako najstarsze w Polsce, ale zagadnienie to wymaga dalszych badań porównawczych.

${ }^{123}$ S. Nakielski, Miechovia..., dz. cyt., s. 850.

${ }^{124}$ Zob. w tym artykule przypisy 130, 132, 133 i odpowiadający im tekst.

${ }^{125}$ Zob. w tym artykule przypis 26 i odpowiadający mu tekst.

${ }^{126}$ S. Nakielski, Miechovia..., dz. cyt., s. 738 . 
Mona Wyznawcy, Tyburta Męczennika, Machabeusza, Feliksa Męczennika, Nabora Męczennika, Dezydera (Dezyderiusza?) oraz głowę św. Arderina Biskupa i Wyznawcy ${ }^{127}$. Nie wiemy, czy były one złożone na ołtarzach, jak w kościele na Stradomiu, czy też przeznaczono dla nich osobne pomieszczenie. Z opisu kościoła miechowskiego pochodzącego z 1783 roku dowiadujemy się o istnieniu „kaplicy relikwialnej”, trudno jednak stwierdzić, kiedy ona powstała (opis z 1783 roku dotyczy kościoła odbudowanego po wielkim pożarze $)^{128}$.

Bogaty program religijny wyłania się także z wezwań wewnętrznych kościoła św. Jadwigi na Stradomiu. Nakielski był, jak wiadomo, prepozytem klasztoru św. Jadwigi. W 1623 roku odnowił on ołtarze w kościele tego domu, a w swym dziele podał szczegółowe informacje o ich wezwaniach i usytuowaniu ${ }^{129}$.

Kolejność świętych w dedykacji ołtarza głównego była następująca: św. Jakub Mniejszy Apostoł, św. Augustyn, św. Jadwiga i św. Elżbieta. Nakielski podał, że pierwszej konsekracji tego ołtarza dokonał w 1428 roku Jarosław, biskup laodycejski. Odnotował również, że w tym ołtarzu były złożone relikwie św. Justa i św. Leonardy Dziewicy $^{130}$. W dedykacji ołtarza głównego dostrzegamy charakterystyczny zestaw wezwań - dwa z nich są powtórzeniem dedykacji kościoła (św. Jadwiga i św. Elżbieta), dwa zaś odzwierciedlają własny kult bożogrobców (św. Augustyn i św. Jakub Mniejszy). Ołtarz koło zakrystii nosił, powołując się znów na Nakielskiego, wezwanie Grobu Pańskiego i św. Heleny. Posiadał relikwie św. Walerego Męczennika. Tu z kolei należy podkreślić zestawienie dwóch typowych dla bożogrobców wezwań - Grobu Pańskiego i św. Heleny. Oba kulty były bardzo silne w zakonie ${ }^{131}$, tym bardziej więc zastanawia brak przekazów o patrocinium św. Heleny w samym Miechowie. Trzeci ołtarz stał „koło kraty żelaznej” i dedykowany był N. Marii Pannie. Znajdowały się w nim relikwie św. Seweryna Męczennika. Ostatni z wymienionych, czwarty, stał „a latere superioris” i nosił wezwanie św. Anny. Spoczywały w nim relikwie św. Fortunata Męczennika. Dodać jeszcze trzeba, że kościół stradomski posiadał pucharek

${ }^{127}$ S. Nakielski, Miechovia..., dz. cyt., s. 737.

${ }^{128}$ AKM, AV 54, s. 340-361.

${ }^{129}$ S. Nakielski, Miechovia..., dz. cyt., s. 630-631 cytuje te dokumenty z kopii sporządzonej w 1623 roku. Jedynym opracowaniem dziejów tego kościoła jest artykuł S. Tomkowicza, Klasztor szpitalny św. Jadwigi, „Rocznik Krakowski” 22 (1929), s. 59-79 (zob. o ołtarzach na s. 76-77). Uwzględnienie przekazu Nakielskiego pozwala na istotne uzupełnienie niepełnego obrazu tego kościoła, jaki przedstawiłem w książce Średniowieczne patrocinia krakowskie, dz. cyt., s. 85-86.

${ }^{130}$ S. Nakielski, Miechovia..., dz. cyt., s. 883 .

${ }^{131}$ O kulcie św. Heleny zob. T. M. Trajdos, Miechowici w ziemi przemyskiej za panowania Władysława II Jagiełty, „Folia Historica Cracoviensia” 4 (1998), s. 91. 
św. Jadwigi, spełniający funkcję relikwii ${ }^{132}$. Wspomnimy jeszcze, że Samuel Nakielski zacytował in extenso dwa dokumenty z 9 października 1541 roku dotyczące konsekracji, dokonanych przez Dominika, biskupa laodycejskiego - dwóch ołtarzy w kościele św. Jadwigi, prawdopodobnie innych, niż te, które wyżej opisano. Przy pierwszym z nich wystąpiła rozbudowana, ale niepełna, dedykacja świąt maryjnych, a mianowicie Niepokalanego Poczęcia, Narodzenia i Ofiarowania. Przy tym ołtarzu były także wezwania św. Józefa, św. Jana Apostoła, św. Jakuba Apostoła, św. Doroty i św. Apolonii. Drugi z ołtarzy był dedykowany Najświętszej Maryi Pannie, ale było przy nim także wezwanie św. św. Abrahama, Izaaka, Jakuba, Jana Chrzciciela, Rozesłania Apostołów, Wawrzyńca, Wita, Fabiana i Sebastiana, oraz św. Małgorzaty. Nakielski odnotował, że w ołtarzu tym były relikwie św. Aleksandra, 10 Tysięcy Rycerzy Męczenników i Tysięcy świętych Dziewic ${ }^{133}$. Posiłkując się tymi wzmiankami, można zidentyfikować wezwania ołtarza głównego oraz 5 ołtarzy bocznych. Charakterystycznymi cechami programu religijnego kościoła stradomskiego jest obecność i wzajemnie przenikanie się kultów typowych dla bożogrobców (Grób Boży, św. Helena, św. Jakub Mniejszy, św. Augustyn, Rozesłanie Apostołów), kultów dynastycznych (św. Jadwiga i św. Elżbieta, Rozesłanie Apostołów) oraz licznych kultów ogólnej proweniencji.

Nie mamy żadnych szczegółowych informacji o wezwaniach wewnętrznych w innych kościołach administrowanych przez bożogrobców. Na podstawie protokołu powizytacyjnego z końca XVI wieku można ustalić, że kaplica szpitalna w Żarnowcu miała 2 ołtarze ${ }^{134}$, tyle samo było w Chodowie ${ }^{135}$. Po trzy ołtarze posiadały kościoły w Wrocieryżu ${ }^{136}$, Uniejowie ${ }^{137}$, Sławicach ${ }^{138}$, Wrocimowicach ${ }^{139}$, Racławicach ${ }^{140}$ i Chełmie ${ }^{141}$. Nie posiadam danych o ich wezwaniach, nie znam także liczby ołtarzy kościoła w Skaryszewie. Nakielski napisał, że w 1470 roku prepozyt Jan ufundował własnym kosztem ołtarz główny w kościele parafialnym w Skaryszewie, nie podał jednak jego wezwania ${ }^{142}$. Własne ołtarze miały, jak wiadomo, konfraternie. W 1435 roku biskup Zbigniew Oleśnicki erygował bractwo

${ }^{132}$ M. Starnawska, Świętych życie po życiu..., dz. cyt., s. 124.

${ }_{133}$ S. Nakielski, Miechovia..., dz. cyt., s. 630-631.

${ }^{134}$ AKM, AVCap 10 k. 84.

${ }^{135}$ AKM, AVCap 15, k. 40.

${ }^{136}$ AKM, AVCap 10, k. 84v.

${ }^{137}$ AKM, AVCap 15, k. 41v- 42V.

${ }^{138}$ AKM, AVCap 10, k. 132.

${ }^{139}$ AKM, AVCap 10, k. 141.

${ }^{140}$ AKM, AVCap 10, k. 143.

${ }^{141}$ AKM, AVCap 7, k. 175.

${ }^{142}$ S. Nakielski, Miechovia..., dz. cyt., s. 543. Może wówczas pojawiło się w Skaryszewie wezwanie św. Jakuba Mniejszego? 
Miłosierdzia Bożego i św. św. Piotra i Pawła w kościele skaryszewskim ${ }^{143}$. Można przypuszczać, że był tam także ołtarz św. Anny, bowiem w 1593 roku nastąpiło erygowanie bractwa jej dedykowanego ${ }^{144}$.

W podsumowaniu zostanie przedstawionych kilka roboczych wniosków. Należy podkreślić, że książka historyka zakonu, Samuela Nakielskiego, dostarczyła wielu informacji o patrociniach. Porównanie ich z wzmiankami zawartymi w źródłach średniowiecznych, jak i wykazane na kilku przykładach powoływanie się kanonika na stare źródła klasztorne, pozwala widzieć w relacji Nakielskiego wartościowy przekaz źródłowy, mogący stanowić istotne uzupełnienie średniowiecznych wzmianek. Wysoka ocena wiarygodności Nakielskiego nie zwalnia, z przeprowadzenia szczegółowej analizy wezwań. W niniejszym artykule mogła ona być co najwyżej zasygnalizowana. Uważamy za wiarygodne informacje Nakielskiego o posiadaniu przez kościół miechowski relikwii w postaci ziemi i kamieni z Grobu Pańskiego i drzazgi Krzyża Świętego. Niewątpliwie były też inne, ale w tej kwestii dotkliwy jest brak źródeł. Zapiski odnoszące się do 1584 roku ukazują typowe zjawisko pozyskiwania przez zakon nowych partykuł.

Jeśli idzie o problematykę wezwań, to można pokusić się o stwierdzenie, że bożogrobcy mieli wpływ na powstanie złożonych dedykacji nie tylko w kościołach, do których powstania się przyczynili, ale także i w tych, które zostały im ofiarowane w gotowej postaci. Do już istniejących tytułów kościołów lub ołtarzy dodawali nowe patrocinia, wzbogacając w ten sposób program religijny swoich świątyń. Pełny tytuł kościoła w Miechowie obejmował patronat Grobu Pańskiego, Ducha Świętego i N. Marii Panny. Kościół w Żarnowcu był pw. Znalezienia Krzyża Świętego, Podwyższenia Krzyża Świętego, Grobu Pańskiego i Nawiedzenia N. Maryi Panny. Pod wpływem kanoników kościół w Chodowie otrzymał dedykację Nawiedzenia N. Maryi Panny, św. Jana Chrzciciela, św. Jana Ewangelisty i św. Małgorzaty. Ich inspiracji możemy się domyślać także w rozbudowaniu dedykacji kościoła we Wrocieryżu, który w swym tytule otrzymał, po przejęciu go przez zakon, wezwania N. Marii Panny, św. św. Marcina, Stanisława, Wacława, Floriana, Wojciecha, Wawrzyńca, Wszystkich Apostołów i Ewangelistów, św. św. Katarzyny, Barbary, Małgorzaty i Doroty.

Źródła odnoszące się do średniowiecza pozwalają zaobserwować rozwój kultów typowych dla miechowitów. Dwukrotnie w dedykacjach głównych pojawiło się wezwanie Grobu Pańskiego (Miechów i Żarnowiec). Wezwanie to wystąpiło

${ }^{143}$ ZDK 2, nr 343; por. R. Skrzyniarz, Kanonicy Grobu Bożego..., dz. cyt., s. 361, który pisze o bractwie Miłosierdzia.

${ }^{144}$ S. Nakielski, Miechovia..., dz. cyt., s. 777. 
także trzy razy przy kaplicach i ołtarzach w Miechowie oraz przy ołtarzu w kościele na Stradomiu. Patron zakonu, św. Jakub Mniejszy, miał swoje upamiętnienie w tytule kościoła w Skaryszewie oraz w ołtarzach głównych w Miechowie i na Stradomiu. Wezwanie św. Augustyna pojawiło się przy ołtarzach w Miechowie i na Stradomiu znaczenie tego drugiego kościoła podkreślimy także ze względu na potwierdzone tam patrocinium św. Heleny oraz Rozesłania Apostołów. Oba te kościoły odgrywały niewątpliwie najważniejszą rolę w zakonie. Kult św. Krzyża, również typowy dla bożogrobców (i innych zakonów) przejawił się w rozbudowanej dedykacji kościoła w Żarnowcu, gdzie upamiętniono oba święta krzyżowe, oraz w tytule kaplicy w Siedliskach. Wyraźnie promowana wydaję się również patrocinia Ducha Świętego.

Miechowskie wezwanie św. Barbary, podobnie jak występujące w innych kościołach badanej grupy, patrocinia św. św. Magdaleny, Katarzyny, Doroty, i Małgorzaty wskazują na silny kult świętych Dziewic i Męczenniczek. Jest to zjawisko typowe dla średniowiecznej diecezji krakowskiej, wyraźne dowody ich kultu odnajdujemy także w ołtarzach i kaplicach bazyliki miechowskiej. Na podkreślenie zasługuje również upamiętnienie wszystkich czterech patronów Królestwa Polskiego w dedykacji kościoła we Wrocieryżu. W przypadku kościoła na Stradomiu możemy mówić o wielkim znaczeniu bożogrobców dla promowania, dokonywanego przez wezwanie główne - kultu św. Jadwigi Śląskiej, zaliczanej także do patronów królestwa.

Podkreślić należy również występowanie w dedykacjach kościołów omawianego zakonu wezwań do N. Marii Panny (już przed 1242 roku w Miechowie), w tym $\mathrm{z}$ wczesną, datowaną na przełom XIV/Xv wieku, atrybucją święta Nawiedzenia (Chodów i Żarnowiec). Pojawiły się też w dedykacjach głównych patrocinia św. Jana Chrzciciela, św. Jana Ewangelisty, św. Marcina, św. Małgorzaty, św. Wita, św. Andrzeja, św. św. Piotra i Pawła.

Źródła w postaci „Rocznika miechowskiego”, jak i opartej na zaginionych materiałach pracy Samuela Nakielskiego, dostarczyły mnóstwo informacji do zagadnienia patrociniów wewnętrznych. W kościele miechowskim jako wezwania ołtarzowe wymieniono wezwania Grobu Bożego, św. Katarzyny, św. Jana Ewangelisty, św. Mikołaja, św. Marcina, św. Jakuba Większego Apostoła, św. Jakuba Mniejszego Apostoła, św. Filipa Apostoła, św. Michała Archanioła, św. Łazarza, św. Marty, św. Marii Magdaleny, św. Agnieszki, św. Doroty, św. Barbary, św. Augustyna, Wszystkich Aniołów, Doktorów Kościoła, Wszystkich Ewangelistów. Wykaz ten można uzupełnić o wezwanie św. Anny, jak również o wezwanie Krzyża św. W kościele na Stradomiu wystąpiły wezwania N. Marii Panny (dwukrotnie), a także szczegółowe: Niepokalanego Poczęcia, Narodzenia i Ofiarowania, św. Józefa, św. Jana Apostoła, św. Jakuba Apostoła, św. Doroty i św. Apolonii, św. Abrahama, 
Izaaka, Jakuba, Jana Chrzciciela, Rozesłania Apostołów, Wawrzyńca, Wita, Fabiana i Sebastiana, oraz św. Małgorzaty, św. Augustyna, św. Jadwigi i św. Elżbiety, Grobu Pańskiego i św. Heleny i św. Anny. Wielka liczba ołtarzy i wezwań wymuszała odpowiednie regulacje w liturgii, pamiętać bowiem należy, że konwentualny kościół miechowski spełniał także funkcję świątyni parafialnej. Wezwania te ukazują promowanie kultów ogólnochrześcijańskich, a także typowych dla Polski, co może służyć jako ilustracja zjawiska pewnego zatarcia się „cech jerozolimskich”"145.

\section{Streszczenie}

Autor przedstawia wyniki własnych badań źródłowych nad zagadnieniem obecności relikwii oraz wezwań występujących w kościołach zakonu bożogrobców, znajdujących się w średniowiecznej Małopolsce (na obszarze województw krakowskiego i sandomierskiego). W artykule zostały ujawnione ważne przekazy w kronice Samuela Nakielskiego. Pierwszy przekaz, znany w literaturze, dotyczy przywiezienia przez Jaksę ziemi z Jerozolimy. Drugi przekaz - o posiadaniu przez klasztor bożogrobców relikwii św. Krzyża nie był dotychczas omawiany w literaturze. Autor stawia tezę o istnieniu w klasztorze miechowskim ważnych relikwii związanych z Męką Pańską. Analizie zostały poddane najważniejsze przekazy źródłowe o wezwaniach. Wskazano, że wezwanie główne kościoła miechowskiego przybrało pod koniec xIII wieku złożoną dedykację do Grobu Bożego, Ducha Świętego i N. Marii Panny. Wiele miejsca autor poświęcił również analizie wezwania kościoła w Żarnowcu, gdzie wystąpiły wezwania do obu świąt związanych z Krzyżem św., do Ducha Świętego, Grobu Pańskiego i N. Marii Panny. Omówione zostały także wezwania pozostałych 10 kościołów administrowanych przez bożogrobców. Autor przedstawił także bogate dane o wezwaniach ołtarzy i kaplic, które zachowały się w odniesieniu do kościoła w Miechowie i kościoła św. Jadwigi na Stradomiu. Wraz z informacjami o licznych relikwiach świętych powinny one stać się punktem wyjścia do dalszych badań.

\section{Słowa kluczowe}

kościoły bożogrobców, Miechów, patrocinia, relikwie, XII-XVI wiek

${ }^{145}$ Zjawisko to dostrzegała M. Starnawska, Krucjata i Ziemia Święta..., dz. cyt., s. 173 w odniesieniu do joannickiej komandorii w Oleśnicy. 


\section{Abstract \\ Churches of the Canons Regular of the Holy Sepulchre. Based on the studies on patrocinia and relics (12th to 16 th c.)}

The author presents the findings of his own studies on the presence of relics and dedications in the churches of Canons Regular of the Holy Sepulchre in medieval Polonia Minor (covering the former Krakow and Sandomierz voivideships). The article reveals important accounts in Samuel Nakielski's chronicle. The first account relates bringing the soil from Jerusalem by Jaksa and is known in literature. The second account concerns the possession of the relics of the Holy Cross by the monastery of Canons Regular of the Holy Sepulchre, hitherto unknown in literature. The author formulates a thesis on the existence of important relics of the Passion in the Miechów monastery. Key source accounts on dedications were analysed. It was indicated that the primary dedication of the Miechów church towards the end of the 18 th century was a combined invocation of the Holy Sepulchre, the Holy Spirit and Blessed Virgin Mary. The author also extensively analyses the dedication of the church in Żarnowiec, with dedications to both feasts related to the Holy Cross, to the Holy Spirit, the Holy Sepulchre and Blessed Virgin Mary. The dedications of 10 other churches administered by Canons Regular of the Holy Sepulchre are also discussed. In addition, the author presents a substantial collection of data on the dedications of surviving altars and chapels in relation to the Miechów church and St Jadwiga's Church in Stradom. In conjunction with the information on numerous relics of saints, the findings should become a departure point for further studies.

\section{Keywords}

Churches of the Canons Regular of the Holy Sepulchre, Miechów, patrocinia, relics, 12th to 16 th $\mathrm{c}$.

\section{Bibliografia}

\section{Źródła}

AKM, Acta Officialatus Cracoviensis, t. 1.

AKM, Acta Officialatus Cracoviensis, t. 38.

AVCap 10, k. 84V, 132, 141, 143.

AVCap 15, k.4O, k. 41v-42V.

Avcap 65, s. 290.

Avcap 7.

Dlb 2, s. 9, 113, 527. 
KMp II, nr 375, 376, 378, 400, 401, 405, 410, 428, 621, 623, 625.

KMP III nr 858, 879 .

ZDK I, nr 162, 181.

ZDM VI, nr 1664 .

\section{Opracowania}

Angenendt A., Heilige und Reliquien. Die Geschichte ihres Kultes vom frühen Christentum bis zur Gegenwart, München 1994.

Backmund N., Monasticon Praemonstratense, id est historia circariarum atque canoniarum candidi et canonici ordinis Praemonstratensis, vol. 3, Straubing 1953.

Beyer F.-H., Geheiligte Räume. Theologie, Geschichte und Symbolik des Kirchengebäudes. Wissenschaftliche Buchgesellschaft, Darmstadt 2008.

Borkowska U., „Pietas regia”. Formy królewskiej pobożności w późnośredniowiecznej Polsce, [w:] Król w Polsce XIV i XV wieku, red. A. Marzec i J. Wilamowski, Kraków 2006, s. 39-56. Borkowska U., Życie religijne polskich Jagiellonów. Zarys problematyki, [w:] Chrzest Litwy. Geneza, Przebieg, Konsekwencje, red. M. T. Zahajkiewicz, Lublin 1990, s. 149-180.

Chojnacki A., Dwie wersje „Rocznika miechowskiego” orazjego nieznana kontynuacja (w świetle analizy „Miechovii” Samuela Nakielskiego), „Hereditas Monasteriorum” 1 (2012), s. 57-71.

Chrzanowski T., Kornecki M., Sztuka ziemi krakowskiej, Kraków 1982.

Dondi C., The Liturgy of the Canons regular of the Holy Sepulchre of Jerusalem: A study and a catalogue of the manuscript sources, Turnhout 2004.

Dunin-Wąsowicz T., Wezwanie św. Jakuba na tle innych patrociniów Sandomierszczyzny, [w:] Sedes Regni principales, red. B. Trelińska, Sandomierz 1999, s. 103.

Ehbrecht W., Überall ist Jerusalem, [w:] Konsens und Konflikt: Skizzen und Überlegungen zur älteren Verfassungsgeschichte deutscher Städte, Hrsg. W. Ehbrecht, P. Johanek, Köln-Weimar-Wien 2001, s. 429-472.

Elm K., Kanoniker und Ritter vom Heiligen Grab. Ein Beitrag zur Entstehung und Frühgeschichte der palästinensischen Ritterorden, [w:] Die geistlichen Ritterorden Europas, Hrsg. J. Fleckenstein i M. Hellman, Sigmaringen 1980, s. 141-169 (Vorträge und Forschungen, 26).

Elm K., Umbilicus Mundi. Beiträge zur Geschichte Jerusalems, der Kreuzzüge, des Ordens der regulierten Chorherren vom Heiligen Grab und der Ritterorden, Brügge 1998 (Instrumenta Canonissarum Regularium Sancti Sepulcri, 7).

Gładysz M., Zapomniani krzyżowcy. Polska wobec ruchu krucjatowego w XII-XIII wieku, Warszawa 2002.

Halaga O., Počatky Košic a zrod metropoly, Košice 1992.

Hehl E. D., Kreuzzug - Pilgerfahrt - Imitatio Christi, [w:] Pilger und Wallfahrtstätten in Mittelalter und Neuzeit, Hrsg. M. Matheus, Stuttgart 1999, s. 35-51. 
Jastrzębowska E., Najstarsze zachowane dewocjonalia pielgrzymie z Jerozolimy, [w:] Jerozolima w kulturze europejskiej, pod red. P. Paszkiewicz, T. Zadrożny, Warszawa 1997, s. 59-71.

Kardyś P., Średniowieczne dyplomy pergaminowe bożogrobców z Miechowa w Archiwum Diecezjalnym w Kielcach, [w:] Rycerze, wędrowcy, kacerze. Studia $z$ historii średniowiecznej i wczesnonowożytnej Europy Środkowej, red. B. Wojciechowska, W. Kowalski, Kielce 2013, s. 177-186.

Kozłowska-Budkowa Z., Płockie zapiski o cudach z r. 1148, „Kwartalnik Historyczny” 44 (1930), s. 341-348.

Kroesen J. E. A., The Sepulchrum Domini through the Ages Its Form and Function, Leuven 2000.

Krüger J., Die Grabeskirche zu Jerusalem. Geschichte - Gestalt - Bedeutung, Regensburg 2000.

Krüger J., Jerusalem - Rom - Santiago. Drei Pilgerziele im Vergleich, [w:] Heiliges Grab Helige Gräber. Aktualität und Nachleben von Pilgerorten, Hrsg. Röper, M. Treml, Berlin 2014, s. 24-32.

Laberschek J., Miechów - klasztor, [w:] Słownik historyczno-geograficzny województwa krakowskiego w średniowieczu, oprac. W. Bukowski, J. Laberschek, A. Marzec, M. Zdanek, przy współpr. S. Kołodziejskiego, cz. IV, z. 2, Kraków 2009.

Łoziński J. Z., Miechowskie Sepulchrum Domini, „Biuletyn Historii Sztuki” 31 (1969), s. $151-165$.

Manikowska H., Geografia sakralna miasta, [w:] Animarum kultura. Studia nad kultura religijna na ziemiach polskich w średniowieczu, t. 1: Struktury kościelno-polityczne, pod red. H. Manikowskiej i W. Brojera, Warszawa 2008, s. 95-131 (Colloquia Mediaevalia Varsoviensia, 4).

Manikowska H., Translatio Jerozolimy do Wrocławia, [w:] Kościół kultura społeczeństwo. Studia z dziejów średniowiecza i czasów nowożytnych, Warszawa 2000, s. 63-75.

Mika N., Bożogrobcy raciborscy $w$ średniowieczu, [w:] Klasztor $w$ mieście średniowiecznym i nowożytnym, red. M. Derwich, A. Pobóg-Lenartowicz, Wroclaw-Opole 20oo, s. 419-426.

Morris C., The Sepulchre of Christ and the Medieval West: From the Beginning to 160o, Oxford-New York 2005.

Nakielski S., Miechovia sive promptuarium antiquitatum Monasterii Miechoviensis, Cracoviae 1634.

Niwiński M., Ród panów na Wierzbicy, „Miesięcznik Heraldyczny” 10 (1931) nr 2, s. 29-35.

Pencakowski P., Przemiany formy i funkcji wieży kościoła parafialnego (dawniej bożogrobców) w Miechowie, „Kwartalnik Architektury i Urbanistyki” 36 (1991) z. 3, s. 207-222. Pietrusiński J., Relikwiarz z Korzkwi, „Biuletyn Historii Sztuki” 43 (1981) nr 2, s. 123-134. Piłat Z., Fundator i fundacja klasztoru bożogrobców w Miechowie, [w:] Bożogrobcy w Miechowie, red. M. Affek, Miechów-Warszawa 1999, s. 11-43. 
Piwoński H., Kult świętych w kalendarzach liturgicznych bożogrobców, „Muzyka Religijna w Polsce" 3 (1979), s. 157-182.

Piva P., Die "Kopien" der Grabeskirche im romanischen Abendland. Überlegungen zu einer problematischen Beziehung, [w:] Die Zeit der Kreuzzüge. Geschichte und Kunst, Hrsg. R. Cassanelli, Stuttgart 2000, s. 96-117.

Pobóg-Lenartowicz A., Kult świętych w śląskich klasztorach kanoników regularnych $w$ średniowieczu, [w:] Ecclesia et civitas. Kościół i życie religijne w mieście średniowiecznym, red. H. Manikowska i H. Zaremska, Warszawa 2002, s. 439-452 (Colloquia Mediaevalia Varsoviensia, 3).

Rajman J., Pilger und Stifter. Zu den Sakralstiftungen und zur Herkunft des Fürsten Jaxa, [w:] Monarchische und adlige Sakralstiftungen im mittelalterlichen Polen, Hrsg. E. Mühle, Berlin 2013, s. 317-346 (Stiftungsgeschichten, 9).

Rajman J., Przyczynki do zagadnienia duchowości zakonu św. Norberta w Polsce, „Nasza Przeszłość" 97 (2002), s. 5-23.

Rajman J., Średniowieczne patrocinia krakowskie, Kraków 2002.

Rajman J., Święta, relikwie i patrocinia w problematyce kultu świętych w Krakowie od końca $\mathrm{x}$ do połowy XıII wieku, [w:] Kraków w chrześcijańskiej Europie, pod red. E. Firlet, Kraków 2006, s. 121-161.

Rajman J., Exemplaris tu columpna. Z problematyki kultu świętej Jadwigi Śląskiej w średniowiecznej Małopolsce, [w:] Memoria viva. Studia historyczne poświęcone pamięci Izabeli Skierskiej (1967-2014), red. G. Rutkowska, A. Gąsiorowski, Warszawa-Poznań 2015, s. 175-190.

Rajman J., Jagiellonowie a klasztor bożogrobców w Miechowie, [w:] Jagiellonowie i ich świat. Dynastia królewska w drugiej połowie XV i w XVI w., pod red. B. Czwojdrak, J. Sperki, P. Węcowskiego, Kraków 2016 (Studia Jagiellonica, 2) [w druku].

Reichert F., Nabel der Welt, Zentrum Europas und doch nur Peripherie? Jerusalem in Weltbild und Wahrnehmung des späten Mittelalters, [w:] „Zeitschrift für Historische Forschung" 38 (2011) nr 4, s. 559-584.

Roth G., Das „Heilige Grab” in Görlitz, [w:] Der Jakobuskult in Ostmitteleuropa: Austausch Einflüsse - Wirkungen, Hrsg. K. Herbers i D. R. Bauer, Tübingen 2003, s. 259-283 (Jakobus Studien, 12).

Rozynkowski W., Nie byli sami. Święci opactwa cysterskiego w Pelplinie, [w:] Pelplin 725. rocznica powstania opactwa cysterskiego. Kulturotwórcza rola cystersów na Kociewiu, red. D. A. Dekański, B. A. Grenz, A. Słyszewska, A. M. Wyrwa, Pelplin-Tczew 2002, s. 59-70.

Rozynkowski W., Patrocinia kościołów cysterek w średniowiecznej Polsce - wokół duchowości zakonu, [w:] Cysterki w dziejach ziem polskich, dawnej Rzeczypospolitej i Europy Środkowej, red. A. M. Wyrwa, A. Kiełbasa, J. Swastek, Poznań 2004, s. 130-154. 
Rozynkowski W., Patrocinia kościołów klasztornych fundacji władców polskich (XI-XV wiek). Wokó patronatu władcy? [w:] Klasztor w państwie średniowiecznym i nowo$\dot{z} y$ tnym, pod red. M. Derwicha, A. Pobóg-Lenartowicz, Wrocław-Opole-Warszawa 2005, s. 31-44.

Rozynkowski W., Św. Józef, patron kościołów zakonnych w Polsce ok. 1772 roku, „Kaliskie Studia Teologiczne" 3 (2004), s. 131-137.

Rozynkowski W., Święci patronowie kościoła dominikanów w Gdańsku - wokół średniowiecznych wezwań dominikańskich w Polsce, [w:] Dominikanie. Gdańsk - Polska Europa, pod red. D. A. Dekańskiego, A. Gołembnika, M. Grubki, Gdańsk-Pelplin 2003, s. 243-253.

Rozynkowski W., Wezwania kościołów kanoników regularnych laterańskich $w$ Polsce, ufundowanych do końca Xv wieku. Zarys problematyki, [w:] Święty Stanisław Kazimierczyk CRL (1433-1489). Postać, środowisko, kultura, dziedzictwo, pod red. K. Łataka, Kraków 2010, s. 247-258.

Ryś G., Teologia relikwii w średniowieczu, [w:] Kult świętych w Polsce średniowiecznej, red. E. Piwowarczyk, R. M. Zawadzki, Kraków 2003, s. 27-36.

Schuchard C., Zur Stiftungstätigkeit der Hohenzollern und ihrer Vertrauten in der Mark Brandenburg im 15. und frühen 16. Jahrhundert, [w:] Die Mark Brandenburg unter den frühen Hohenzollern. Beiträge zu Geschichte, Kunst und Architektur im 15. Jahrhundert, Hrsg. P. Knüvener, D. Schumann, Berlin 2015, s. 35-59.

Sczaniecki P., Sacramentum dedicationis. Obrzęd poświęcenia kościoła i jego znaczenie $w$ dziedzinie religijnej, obyczajowej i kulturalnej na podstawie źródeł staropolskich $z$ XII wieku, Lublin 1979.

Skierska I., Obowiązek mszalny w średniowiecznej Polsce, Warszawa 2003.

Skrzyniarz R., Duchowość zakonu bożogrobców, [w:] Ludzie. Kościół. Wierzenia. Studia $z$ dziejów kultury i społeczeństwa Europy Środkowej (średniowiecze - wczesna epoka nowożytna). Księga pamiątkowa poświęcona Prof. Stanisławowi Bylinie, red. W. Iwańczak, S. K. Kuczyński, Warszawa 2001, s. 49-59.

Skrzyniarz R., Kanonicy Grobu Bożego i ich religijny, społeczny, edukacyjny i kulturowy wkład $w$ rozwój mieszkańców ziem polskich $w$ średniowieczu, Lublin 2015.

Starnawska M., Krucjata i Ziemia Święta $w$ duchowości zakonów krzyżowych w Polsce średniowiecznej, „Saeculum Christianum” 3 (1996) nr 1, s. 167-179.

Starnawska M., Między Jerozolima a Łukowem. Zakony krzyżowe na ziemiach polskich $w$ średniowieczu, Warszawa 1999.

Starnawska M., Rozmieszczenie i struktura zbiorów relikwii w polskich miastach średniowiecznych. Problematyka badawcza, [w:] Ecclesia et civitas. Kościół i życie religijne w mieście średniowiecznym, red. H. Manikowska, H. Zaremska, Warszawa 2002, s. 453462 (Colloquia Mediaevalia Varsoviensia, 3). 
Starnawska M., Świętych życie po życiu. Relikwie w kulturze religijnej na ziemiach polskich $w$ średniowieczu, Warszawa 2008.

Starnawska M., Działalność szpitalna zakonów krzyżowych $w$ miastach średniowiecznych na ziemiach polskich, [w:] Klasztor $w$ mieście średniowiecznym i nowożytnym, red. M. Derwich, A. Pobóg-Lenartowicz, Wrocław-Opole 2010, s. 257-268 (Opera ad historiam monasticam spectantia, Series I, Colloquia 4).

Starnawska M., Grunwald, Jerozolima i święto Rozesłania Apostołów, [w:] Conflictus magnus apud Grunwald 1420. Między historia a tradycją, red. K. Ożóg, J. Trupinda, Malbork 2013, s. 221-228.

Szczepkowska-Naliwajek K., Relikwiarze średniowiecznej Europy od IV do początku XVI wieku. Geneza, treści, styl i technika wykonania, Warszawa 1996.

Szymański A., Patrocinia Krzyża Świętego w Polsce, „Studia Teologiczno-Historyczne Śląska Opolskiego" 27 (2007), s. 137-156.

Tobiasz M., Bożogrobcy w Miechowie (w 8oo-lecie sprowadzenia zakonu do Polski), „Nasza Przeszłość” 17 (1963), s. 5-6o.

Tomkowicz S., Klasztor szpitalny św. Jadwigi. „Rocznik Krakowski” 22 ( 1929), s. 80-96.

Trajdos T. M., Miechowici w ziemi przemyskiej za panowania Władysława II Jagiełty, „Folia Historica Cracoviensia" 4 (1998), s. 67-98.

Warmbrunn P., Das ehemalige Kloster vom Heiligen Grab in Speyer, [w:] Festschrift für Jürgen Keddigkeit zum 65. Geburtstag, Hrsg. B. Schuttpelz, P. Roland, Kaiserslautern 2012, s. 11-30 (Kaiserslauterer Jahrbuch für pfälzische Geschichte und Volkskunde, 12).

Wędzki A., Miechów w średniowieczu. Studia z dziejów miasta i klasztoru, zagadka Jaksy, Warszawa 2014.

Witkowska A., Das Patrozinium des Hl. Apostels Jakobus in der mittelalterlichen Diözese Krakau, [w:] Der Jakobuskult in Ostmitteleuropa, Hrsg. K. Herbers i D. R. Bauer, Tübingen 2003, s. 113-136.

Wojciechowski L., Parafia w Miechowie w okresie przedrozbiorowym, [w:] Bożogrobcy $w$ Miechowie, red. M. Affek, Warszawa 1999, s. 57-78.

Wolnik F., Kalendarz nyskich bożogrobców według XIV-wiecznego Liber Ordinarius, „Studia Teologiczno-Historyczne Śląska Opolskiego" 15 (1995), s. 311-333.

Wolnik F., Tajemnica Krzyża w liturgii nyskich bożogrobców, „Studia Teologiczno-Historyczne Śląska Opolskiego" 16 (996), s. 289-312.

Wolnik F., Święci w zabytkach liturgicznych nyskich bożogrobców, [w:] Człowiek i Kościót w dziejach: księga pamiątkowa dedykowana księdzu profesorowi Kazimierzowi Doli z okazji 65. rocznicy urodzin, red. J. Kopiec, N. Widok, Opole 1999, s. 147-165.

Žemlička J., Wallfahrten aus Böhmen nach dem Heiligen Land und ihre kulturelle Bedeutung (bis Mitte des 12. Jahrhunderts), [w:] Wallfahrten in der europäischen Kultur. Pilgrimage in European Culture, Hrsg. D. Doležal, H. Kühne, Frankfurt am Main 2006, s. 37-52. 